AN OUTLINE OF THE

\title{
PIRQUET SYSTEM OF NUTRITION
}

\author{
By \\ DR. CLEMENS PIRQUET
}



Digitized by the Internet Archive in 2007 with funding from Microsoft Corporation 


\title{
AN OUTLINE OF THE \\ PIRQUET SYSTEM OF NUTRITION
}

\author{
By beter
}

DR. CLEMENS PIRQUET

Professor of Pediatrics at the University of Vienna, Austria

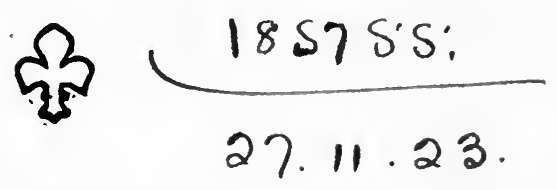

PHILADELPHIA AND LONDON

W. B. SAUNDERS COMPANY

1922 
Copyright, 1922, by W. B. Saunders Company

MADE IN U. 8. A.

PRES6 OF

W. B. BAUNDERS COMPANY

PHILADELPHIA 


\section{INTRODUCTION}

IN the years 1917-1919 I published my new System of Nutrition in four volumes. It is written in German and is rather too large for medical practitioners, as it contains many detailed protocols of the scientific material upon which the system is based.

When I was invited to be a Silliman Lecturer at Yale University in the winter of 1921-1922 several of my lectures on Modern Pediatrics were on this subject of nutrition, and I was asked by many friends to prepare a short book in English which would contain the principal facts and the practical application of the system.

I have used these lectures as a basis for the present book and have added a complete bibliography of the subject from the years 1917-1922, the nem values of the principal food-stuffs, and a table of Pelidisi Indices.

May I use this opportunity to thank Drs. Lewellys F. Barker, Harriette Chick, Elsie Dalyell, Alfred F. Hess; Edward A. Park, and Charles L. Summers, who were kind enough to help me with the English edition in the way of translation and correction.

Clemens Pirquet.

VIENNA, AUstria, August, 1922. 



\section{CONTENTS}

Body Measudemcents and Nutrition............ 11

Calories and Nems...................... 23

Feeding in the First Year of Life............. 35

Nutritional Treatment of TUberculosis.........4 46

Proper feeding as Preventive Medictne.......... 58

Bibliography. ...................... 68

Ney Value of the Princtpal food-stufrs......... 79

Pelmisi Table ........................ 89 



\section{An Outline of the \\ Pirquet System of Nutrition}

\section{BODY MEASUREMENTS AND NUTRITION}

\section{Sitting Height and Body Weight}

THE problem of the body weight of children is one which I have had under consideration for a long period of time. How may we know objectively in making a physical examination whether a child has the amount of muscular and fatty tissue corresponding to his height and skeleton? In a former work I attempted an empiric solution of the problem by comparing Camerer's median weights for the various ages with the median heights, and on the basis of these computing the average weight for any given height.

In studying the relationships existing between the heart, pulse-rate, and body weight I discovered accidentally that a measure hitherto used but little-i. e., the sitting height (height of the trunk)-stands in very close relationship to the cube root of the body weight.

The sitting height is the height of the trunk measured from the surface of the seat on which the body rests 


\section{THE PIRQUET SYSTEM OF NUTRITION}

to the top of the head. This is ascertained very simply by measuring the distance between the horizontal seat and a horizontal board resting on the head.

The sitting height is perhaps not a theoretically exact measure, for it depends upon the position of the spine and the compression of the intervertebral disks. Hence it varies with the position of the body as well as with the period of the day when it is taken, but the standing height is open to the same objections. Every unit of measurement which is not applied exclusively to a rigid bone, but includes also joints, cannot be considered as being mathematically exact.

In measuring the sitting height a child should be made to sit as erect as possible. With a little practice the limits of error will fall within $1 \mathrm{~cm}$. in either direction. Young infants are not measured in the upright position, but horizontally. With them the distance is measured between a vertical board pressed against the seat and another placed against the head.

I desire to present here only a few examples gathered from a large mass of anthropometric material, which have special reference to the problem under discussion.

Measurements of Standing Height, Sitting Height, and Weight

$\begin{array}{ccc}\begin{array}{c}\text { Standing } \\ \text { height, } \\ \text { cm. }\end{array} & \begin{array}{c}\text { Sitting } \\ \text { height, } \\ \text { cm. }\end{array} & \begin{array}{c}\text { Weight, } \\ \text { kg. }\end{array} \\ 26.6 & 17 & 0.35 \\ 50.5 & 32 & 2.9 \\ 116.0 & 66 & 22.3 \\ 177.0 & 93 & 73.3\end{array}$

1. Fetus (about 70 days old). 26.6

2. Newborn........... 50.5

3. Eight years old....... 116.0

4. Adult.............. 177.0

93

73.3 
The differences existing between the smallest and the largest individuals are very great. The standing height advances from 26.6 to $177 \mathrm{~cm}$. Hence the adult is 6.6 times taller than the fetus. The sitting height shows a somewhat smaller variation-17 to $93 \mathrm{~cm}$., i. e., $1: 5.5$. The weight, on the other hand, shows a range from 350 to 73,300 grams, i. e., $1: 220$.

The legs constitute the largest factor in the differences between the standing height and sitting height. The legs of the fetus and the newborn child are relatively short.

We will now consider the ratio of the cube root of the weight and the sitting height.

Fetus. Newborn. Eight years Adult. old.

Weight in grams........... $350 \quad 2900 \quad 22,300 \quad 73,300$

$\begin{array}{llllll}\text { Cube root of above......... } & 7.04 & 14.3 & 28.1 & 41.9\end{array}$

$\begin{array}{lllll}\text { Sitting height............. } & 17.0 & 32.0 & 66.0 & 93.0\end{array}$

Ratio $\sqrt[3]{\text { weight }}$ : sitting height $\quad 0.415 \quad 0.446 \quad 0.426 \quad 0.450$

This ratio represents a variation of only 0.415 to 0.45. The difference in this ratio for the fetus and the adult is only $100: 108$, while the sitting heights have a ratio of $100: 547$, and the weights of $100: 22,000$.

The relationship becomes evident without computing the ratio if instead of employing the cube root of the actual weight we take that of the weight multiplied by 10 . This cube root and the sitting height differ but little: 15.2 and 17, 90.1 and 93 . 


\section{THE PIRQUET SYSTEM OF NUTRITION}

Fetus. Newborn. Eight years Adult.

old.

Weight in grams $\times 10 \ldots \ldots 350029,000 \quad 223,000 \quad 733,000$

$\begin{array}{lllll}\text { Cube root of above.......... } 15.2 \quad 30.7 \quad 60.5 & 90.1\end{array}$

Sitting height, centimeters.... $17.0 \quad 32.0 \quad 66.0 \quad 93.0$

Ratio.................89.0 $96.0 \quad 92.0 \quad 97.0$

The variation in the ratio, ranging between 89 and 97, is furthermore equalized by the fact that the thin fetus and the thin eight-year-old boy show similar values, as do also the robust newborn boy and the adult of average stature. Hence it is evident that the relationship existing between sitting height and weight is a close one.

The relationship becomes still more distinct and simple if we select other more illustrative cases:

\begin{tabular}{|c|c|c|c|}
\hline Weight in grams $\times 10 \ldots$ & $\begin{array}{c}\text { Fetus } \\
\text { about } \\
90 \text { days } \\
\text { old. } \\
6000\end{array}$ & $\begin{array}{c}\text { Newborn. } \\
27,000\end{array}$ & $\begin{array}{l}\text { Adult. } \\
720,000\end{array}$ \\
\hline Cube root of above........... & . 18.2 & 30 & 89.5 \\
\hline Sitting height in centimeters. ..... & . 18.5 & 30 & 90.0 \\
\hline Ratio................... & . 98.4 & 100 & 99.5 \\
\hline Cube of sitting height. & 6332 & 27,000 & 729,000 \\
\hline Weight in grams $\times 10 \ldots \ldots \ldots \ldots$ & .6000 & 27,000 & 720,000 \\
\hline
\end{tabular}

A cube of which one side is the sitting height-i. e., a cube in which the human being can sit upright-if filled with water would represent ten times the weight 
of the human body; or, in other words, this cube is capable of holding 10 persons closely packed.

We could also express this law by saying that the cube root of ten times the weight in grams approximately equals the sitting height in centimeters.

or also

$$
\sqrt[3]{10 \text { weight }}=\text { sitting height }
$$

$$
\frac{\sqrt[3]{10 \text { weight }}}{\text { sitting height }}=1=\frac{100}{100}
$$

If the weight is higher than usual, the ratio will be more than $\frac{100}{100}$. For instance, if a man of $90 \mathrm{~cm}$. sitting height weighs 72.9 kilograms, his weight exactly corresponds to the rule, as the cube root of 729,000 is 90. But if he weighs 10 kilograms more, the formula would be

$$
\frac{\sqrt[3]{829000}}{90}=\frac{104}{100}
$$

If, on the other hand, this man loses 10 kilograms of his weight and weighs only 62.9 instead of 72.9 , the formula would be

$$
\frac{\sqrt[3]{629000}}{90}=\frac{95}{100}
$$

Therefore, we have a formula by which we can judge whether the actual weight corresponds to the average 


\section{THE PIRQUET SYSTEM OF NUTRITION}

weight expected of an individual of a given sitting height.

To make the formula easier to remember I coined a word out of the initials of the constituents: $P$. stands for Pondus, the body weight in grams. $\mathrm{Pe}$ recalls the fact that we have to take not the simple weight, but pondus decies, ten times the weight. $L i$ tells us that the weight must be converted into a linear function by taking the cube root of it. $D i$ means division and $S i$, sitting height. The word, therefore, is pelidisi. We say the pelidisi of this man of $90 \mathrm{~cm}$. sitting height and 72.9 kilograms is 100 ; if he puts on 10 kilograms more weight, it will be 104; if he loses 10 kilograms, it will be 95 .

It would be asking too much of the physician to estimate the cube root of the weight of every patient and afterward perform a division. But this calculation is very easy if he uses a table, where he has only to look for the headings and go down a line of figures until he finds the weight. At the angle he then finds the pelidisi. (See Pelidisi Table on page 89.)

I have not the space here to present all the material on which we tested this formula. We applied it to more than 500,000 individuals, and I wish to give only a résumé of what we found.

The variations in the ratio for all age groups are similar. Children who have much fatty tissue reach the 100 mark, while the thin individuals remain below 
90. In the case of adults, in addition to the fatty tissue we must also take account of the musculature, which raises the index about 5 points. Thin persons fall under 95, adipose persons range over 105.

Why is it that notwithstanding the growth of the extremities and their correspondingly increased weight, the sitting height maintains a uniform relation to the height of the body in all stages of growth from the fetal to adult life? This is due to the fact that the weight of the extremities is compensated by the weight of the head. What is lacking in weight with respect to the extremities of the fetus is made up by the weight of the head.

Hence we may use the determined ratio "Pelidisi" for any individual as an index of changes in the nutritional state of that individual.

\section{Sitring Height and Intestinal SuRface}

As a theoretical point of departure in the consideration of nutritional states, Rubner, to whom we owe the fundamentals of our modern conception of nutrition, adopted the amount of heat given off by the animal at rest and during hunger. The heat of the body is created by the oxidation of the reserve substances of the body, particularly fat. Heat depends upon two factors. On the one hand, it is a by-product of the oxidation necessary to maintain the life functions of the organism, such as the action of the heart and the lungs, the secretion of the glands. On the 


\section{THE PIRQUET SYSTEM OF NUTRITION}

other hand, in a cold environment it is augmented by more or less spontaneous movements in an attempt to avoid cooling of the body and to maintain a uniform internal temperature.

But deprivation of food and rest are exceptional conditions of life which, although admitting of important physiological conclusions, have little significance ordinarily. During normal times there is no general condition of hunger, and we daily satisfy our desire for food. Rest also may be tested experimentally only on patients lying in bed. Generally speaking, the brain worker corresponds more nearly than any other to the conditions imposed by the experiment. The growing and active child, the man engaged in manual labor, are far removed from the conditions of muscular rest and deprivation of food, and hence show an altogether different type of oxidation from that of the physiologic experiment.

As a rule the human organism takes in far larger masses of food than suffice for heating its furnace and maintaining the body temperature. The workingman does not eat for the purpose of keeping his body temperature from falling. On the contrary, he possesses a superabundance of heat which he seeks to eliminate by evaporation.

I assume, therefore, as a starting-point of the theory of nutrition not the amount of heat given off by the body, but the amount of oxidizable intake in the form of food. 
A good point in Rubner's theory is that it brings the oxidation in connection with a surface and not with a cube; but I differ with him in regard to which surface and in regard to whether we should take as a basis the output of heat or the intake of combustible food.

The law that the production of heat corresponds to a surface and not to a cube has, long before Rubner, been expressed by Rameaux in 1838, and by Bergman in 1847; the theory that the output of heat is not the real standard has been brought forward by $H$. von Hoesslin in 1888. The absorbed oxygen, this author pointed out, is proportionate to the amount of oxygen which is circulating in the body. That amount has a relation to the cross-section surface of the bloodvessels, and this again is proportionate to the twothirds power of the weight. Also, the amount of food taken in the body is related to a theoretical intestinal surface, which surface again is related to the surface of a section of the body, and, therefore, to a two-thirds power of weight. Without knowing of the work of Hoesslin, I myself had come to similar conclusions as to the importance of the two-thirds power of the weight, and I tried to find a way of easy calculation for a surface which we could take as representing the absorbing surface through which the food taken in the body had to pass. As I knew that the sitting height stood in a constant and simple relation to the cube root of the weight, the two-thirds 
power of the weight could be easily calculated by taking the square of the sitting height. As this surface interested me in regard to the intake, I had to find out whether or not we could bring it into direct relation with the absorbing surface of the intestines, and this could be done in a very simple way.

Henning had found in 1881 that in children as well as in adults the length of the intestinal canal directly corresponds to the sitting height, a thing which seems to us now a matter of course, as every part of the trunk in a well-proportioned individual will be proportionate to the length of the trunk. But he also had found a very simple relation; the length of the intestinal canal on an average equals ten times the sitting height. Direct measurements of the surface of the intestines gave for the undilated canal of an adult about 5000 sq. cm.; for the dilated, about $10,000 \mathrm{~cm}$.; if we take a medium of 7500 sq. cm., this corresponds to an average circumference of about one-tenth of the sitting height. We can, therefore, have a conception of the absorbing surface in multiplying ten times the sitting height by one-tenth of the sitting height, or, in other words, we take the square of the sitting height as a symbol of the absorbing surface. I say as a symbol, for the absorbing surface can never be measured in an exact way, as it is a most variable thing, and as it would always be a point of dispute whether we have to take it empty or filled, with or without the surface of the intestinal glands, crypts, and villi, with or 
without the inner surface of the larger glands. The important point is that here we have a surface that gives us a certain picture of the absorbing surface and that has a direct relation to the two-thirds power of the weight.

The fact that the two-thirds power of the weight has a true relation to the intake of food could be proved easily by comparing the intake of mammals of very different sizes. I give a series of examples taken from various experiments:

Rat......... 181

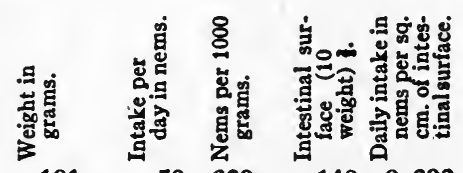

Newborn child........ 2,200

$\begin{array}{llll}58 & 320 & 148 & 0.392\end{array}$

$\begin{array}{llrrrr}\text { Adult................ } & 61,400 & 3,063 & 50 & 7,230 & 0.423\end{array}$

$\begin{array}{llllll}0 x \ldots \ldots \ldots \ldots \ldots \ldots & 632,100 & 15,200 & 24 & 34,200 & 0.445\end{array}$

Highest figure divided by $\begin{array}{llllll}\text { lowest figure......... } & 3,500 & 261 & 13.3 & 231 & 1.14\end{array}$

The ox has a weight 3500 times the weight of the rat, but the food he takes in is not 3500 times more, but only 261 times; compared to weight, the rat eats 13.3 times more than the ox. It is apparent that the intake corresponds much closer to the two-thirds power of the weight, as here the relation of ox to rat is only 231 to 1 . But we see the clearest expression of the law in the last column, which expresses the relation of the daily intake to the intestinal surface: 
The rat takes 0.392 food units per square centimeter, the baby, 0.429, the adult, 0.423 , and the ox, 0.445 ; the division of the highest by the lowest figure gives only 1.14 compared to 231 for surface, 261 for intake, and 3500 for weight.

Having found these simple ways of comparison, I spent about two years in examining the spontaneous intake of children and adults, and comparing these figures with the two-thirds power of the weight and the square of the sitting height. More than 10,000 single day experiments have been used for the calculation. I cannot go into details of this examination, but shall give only the results. The correspondence was remarkably close, and the method of using the square of the sitting height proved to be more satisfactory for practical use because it has the advantage over the two-thirds power of the weight in that it does not depend on the accessory surplus or lack of fat tissue and muscles, but is rather related to an ideal status of nutrition that corresponds to the skeleton.

My task for the following two years was to discover simple principles upon which the feeding of individual children and adults could be based, using the square of the sitting height as a practical index. 


\section{CALORIES AND NEMS}

WE stated in the last chapter that the intake of a newborn baby was 336 food units, and that of an adult 3063 units. These units were not calories, but nems. A "nem" is the nutritive, combustible value of 1 gram of milk, of average human milk. The name is composed of the initials of "Nahrungs-Einheit-Milch," or "Nutrition Equivalent Milk," and refers to a standard human milk of 1.7 per cent. of protein, 3.7 per cent. of fat, 6.7 per cent. of milk-sugar, as well as to a standard cow's milk of 3.3 per cent. of protein, 3.7 per cent. of fat, 5 per cent. of milk-sugar.

Does such a standard milk exist? Does not the milk vary a great deal, and if so, does not each milk present a different standard? Certainly, milk varies greatly, especially in its content of fats, but, nevertheless, we are entitled to take a certain theoretical average as a standard, just as we use the horsepower as a standard for our machines, disregarding the fact that every individual horse has a different power.

The standard milk I chose has a simple relation to the caloric system, having 667 small available calories in 1 gram, or 667 large calories in 1 kilogram; 2000 small calories, therefore 2 large calories equal 3 nems, or one large calory equals 1.5 nems. 


\section{THE PIRQUET SYSTEM OF NUTRITION}

But why not take the calories as they are? Why introduce a new standard? There are several reasons for this. The calory, which dates from Lavoisier's time, has been very well defined for the physicist as the amount of heat necessary to raise the temperature of $1 \mathrm{gram}$ of water $1^{\circ} \mathrm{C}$. - this is the so-called small calory. The large calory raises the temperature of 1000 grams $1^{\circ} \mathrm{C}$. This is clear when a bomb calorimeter is used, but not if the combustion takes place in a living being. A portion of the food ingested is not available for heat production, since a fraction of it passes off from the body undigested. Some of the physiologists distinguish, therefore, the net from the raw calory, some discount the unburned part in the feces, some discount also the unburned output in the urine-the fact is, that every one of the greater schools of physiology has its own definition, and, therefore, arrives at a different caloric value for the food-stuffs of ordinary use.

What we need is a simple physiologic unit. The calory does not supply it. Coal, for instance, is wonderfully rich in calories if you burn it in an oven, but it has no food value, because it passes the intestinal canal without being absorbed. If you burn leafy sprigs in a calorimeter the caloric value may be large, but if you feed the same to cattle you discover not only that the animals are unable to avail themselves of the heat value but also that they actually lose weight because of the work of mastication and of transforma- 
tion of the sprigs into a pulpy mass that can pass through the intestines. Because of this the agriculturists have long ago abandoned the caloric system. They use different physiologic units of comparison, of which, to my mind, the starch unit of Kellner is the best. It compares the amount of fat produced by 1 kilogram of various food-stuffs given as a surplus to a minimum ration with the amount of fat produced by ingestion of 1 kilogram of water-free starch as a standard. Both unit and point of comparison seemed not to be applicable to human beings, for we do not use water-free starch, and our object is not to produce lard. I thought milk much more appropriate for a practical unit, as it is the first food we give to human beings. During childhood we substitute slowly other materials for it. Moreover, it contains all the important food-stuffs, the combustibles (fat and carbohydrates), the structural elements (water and salt), and the proteins which can be used both as structural elements and as combustibles, and finally, the vitamins.

This milk unit is used as a metric unit, and is combined with the Latin prefixes for metric fractions, and with the Greek prefixes for multiples of the unit:

A decinem means one-tenth of a nem, or the nutritive value of 1 decigram of milk, $0.1 \mathrm{gm}$., and is written $1 \mathrm{dn}$.

A centinem is written $1 \mathrm{cn}$., and represents $0.01 \mathrm{gm}$. A millinem is written $1 \mathrm{mn}$., and represents $0.001 \mathrm{gm}$. 
These smaller units are used only in the calculation of the food intake per square centimeter in its relation to the nutritional surface. For instance, in the above example, we would say the baby's intake was 4.29 decinems per square centimeter, or 42.9 centinems, or 429 millinems.

In the practical use of food-stuffs we have to make use of the larger units, namely, the multiples with Greek prefixes:

A dekanem (Dn.) means 10 nems.

A hektonem (Hn.) means 100 nems. This unit is used in the composition of a recipe for a certain dish, or of the day's program for one person or family.

A kilonem (Kn.) means 1000 nems. We use it in buying food-stuffs for a family, or making recipes for a large number.

A tonnenem (Tn.), finally, represents the food value of 1 metric ton of milk: $1000 \mathrm{Kn}$., or 1,000,000 nems. We use it in wholesale nutrition, as in making the budget for the child feeding in Austria where we have been feeding 400,000 meals a day of $1 \mathrm{Kn}$. each. The daily use, therefore, was $400 \mathrm{Tn}$. A train containing 60 cars, 16 metric tons each, has 960 metric tons. If the content is flour, each metric ton means 5 tonnenems, and the train contains 4800 tonnenems. It would give $4,800,000$ meals, or sufficient food for twelve days.

I said that flour has 5 tonnenems in a metric ton. I could just as well have said that it contains 5 kilonems per kilogram, or as the simplest expression, 5 nems 
per gram. Flour has five times the food value of milk weight for weight.

The food values of all articles used for human food should be determined by substituting a given quantity of the article for milk. This method is being worked out for some food-stuffs used in early infancy, but it will take years to finish this experiment for the very many food-stuffs we use for adults. Meantime we use a chemical analysis of the food, discount the percentage of combustibles lost in the urine and in the stools, and translate grams and calories into nems.

To shorten the chemical analysis I devised simple methods of examination, based on the testing of dry substances, fat, and ashes, which are easy to apply, and give results that are satisfactory for practical use. Cow's milk, for instance, has to be examined as to its fat content alone, and bread as to its content in dry substance. (See Nem Value of Principal Foodstuffs, page 79.)

If no special accuracy is required, we content ourselves with the average data, based on chemical examinations of food-stuffs by numerous authors, and collected by König.

I give some of the most important food-stuffs in the following table, which gives at the same time the weight of 1 hektonem in grams: If 1 gram of flour has a food value of 5 nems, 20 grams will contain 100 nems, or 1 hektonem. The "hektonem-weight" of flour, therefore, is 20 . 


\section{THE PIRQUET SYSTEM OF NUTRITION}

Nems in 1 gram.

Hektonem weight.

$13 \frac{1}{3} \quad$ Pure fat, oil............... 7.5

12 Butter....................... 8.5

$30 \quad$ Bacon........................ 10

$6 \quad$ Sugar, cocoa.................. 16.7

5 Wheat flour, oat flour, biscuit, rice, ham, fresh fat meat, cheese, syrup, honey..................... 20

4 White bread.................... 25

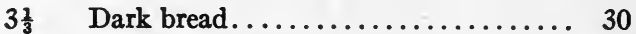

2.5 Fresh meat, eggs................ 40

1.25 Potatoes....................... 80

1 Milk, green peas................ 100

0.67 Fresh fruit..................... 150

0.5 Skimmed milk................ 200

0.4 Turnips, spinach, cabbage, cauliflower, fresh mushrooms............... 250

0.2 Lettuce, cucumbers............. 500

Let us now compose a meal, let us say a good breakfast, for an adult, of 10 hektonems:

Two large cups of coffee with milk:

Food value in hektonems.

$200 \mathrm{gm}$. of water with coffee.............. 0

$200 \mathrm{gm}$. of milk.................... 2

and 2 lumps of sugar in each cup:

$17 \mathrm{gm}$. of sugar.................... 1

Two rolls of white bread with butter:

$50 \mathrm{gm}$. of white bread................. 2

$8.5 \mathrm{gm}$. of butter................... 1

Bacon and eggs:

$80 \mathrm{gm}$. of eggs (2 eggs)................ 2

$20 \mathrm{gm}$. of bacon (2 small slices)............ 2

10 hektonems 
Let us go one step farther. We desire to prepare for a child for supper a gruel of the food value of 4 hektonems:

260 grams of milk-food value of 1 gram is one

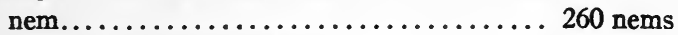

16 grams of oatmeal $(5 \times 16) \ldots \ldots \ldots \ldots \ldots 80$

10 grams of sugar $(10 \times 6) \ldots \ldots \ldots \ldots \ldots 60$

400 nems or $4 \mathrm{hn}$.

You see our way of procedure. It is not a calculation of a given meal, but it is a composition of a meal. Using the food values in nem as the basis for the composition of a meal, one must then decide whether or not the given mixture will taste well. It is not sufficient that the food contain the given amount of nutritive value, but it must be composed and prepared in a way that is appetizing. In this way a great number of 1 kilonem recipes that are pleasing to the taste have been worked out. The following is one example:

Pudding with Mushrooms

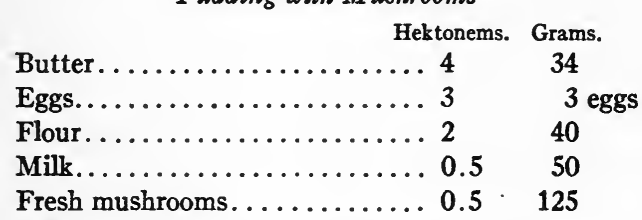

The recipe, of course, gives explicit directions for the preparation of the pudding by the cook, telling how much salt and pepper and onions have to be added, their slight nutritive values being disregarded.

If we feed human beings for a whole day, we have 
not only to consider the combustible content of the food but also the protein content, the water content, furthermore, the content of the food in vitamins, in salts, finally in cellulose and other indigestible substances.

For determination of the necessary content in protein of a diet the physiologists calculate the protein used in metabolism. I approach the topic by a different way, similar to my way of simply taking the spontaneous intake for determining the combustible values. I tried to find out what was natural, as shown in actual habits, of protein intake at different ages, in different countries, and in different animals. I did not try to reach absolute figures in grams of protein per day or per kilogram, but rather considered the protein used in relation to the amount of combustibles.

It appeared that human beings and domestic animals of all ages are accustomed to take at least 10 per cent. of their caloric values in the form of proteins, and rarely take more than 20 per cent. in this form. These two limits are easy to remember. Human milk contains about 10 per cent. and bovine milk about 20 per cent. of protein, and we are safe if we keep within these two limits. A less amount may hamper growth and digestion-growth, because proteins are among the most important substances for the body, and digestion, since the different juices of the gastric intestinal tract need proteins to be effective. If sheep, for instance, are fed with too little protein, they are not able to digest starch. On the other hand, a sur- 
plus of protein is not used as a structural element, but as a combustible, and it is a very bad one, for a part of it leaves the body through the urine unburnt.

The amount of protein contained in the different food-stuffs is also brought in relation to their value in nem. If 10 per cent. of the food value is contained in the form of protein, we may as well say 1 dekanem (Dn.) of protein is contained in every hektonem of this diet. We do not need to make the calculation more accurate than in dekanem, as our object is only to keep within between 10 and 20 per cent.

The food-stuffs mentioned above for their content in nems contain the following amount of protein:

Pure fat, oil, butter............... none Dn. protein in $1 \mathrm{Hn}$.

Sugar, syrup, honey............... none

Bacon......................... 0.5

Potatoes...................... 0.5

Fresh fruit.................... 0.5

Flour, biscuit, rice.............. 1

Bread......................... 1

Human milk. .................... 1

Fresh fat meat. ................. 2

Cow's milk. ................... 2

Green peas................... 2

Turnips, cabbage, cauliflower........... 2

Lettuce and cucumbers............... 2

Ham......................... 3

Eggs......................... 3

Mushrooms.................... 3

Cheese......................... 4

Skimmed cow's milk. .............. 4

Fresh medium meat................ 4 
If, for instance, we had to determine the amount of protein contained in the breakfast we mentioned above, we would say:

Dn. protein.

2 hektonems of cow's milk ( $2 \mathrm{Dn}$. in a Hn.) $2 \times 2.4$

1 hektonem of sugar, none.............. 0

2 hektonems of white bread, 1 Dn........... 2

1 hektonem of butter, none............ 0

2 hektonems of eggs, $3 \mathrm{Dn} . . \ldots \ldots \ldots \ldots \ldots 6$

2 hektonems of bacon, $0.5 \ldots \ldots \ldots \ldots \ldots 1$

This breakfast contains 13 dekanems protein in 10 hektonems of food, or 13 per cent. of the combustible value consists of protein. This is within the limits of our estimation. It is not necessary to look over each meal for the protein amount, not even for each day, but we do it for the control of a week's program.

As to the special value in protein, science is not yet advanced enough to form a clear and simple program. As for the vitamins, we consider the weekly program, to see whether it contains milk, potatoes, and green vegetables.

An important point is the content of the food in non-digestible matter. Small babies do not need it, but older children and especially adults become mostly constipated if they do not ingest a certain amount of cellulose. Our rule is to give every day brown bread at two meals, and once a day green vegetables (spinach, cabbage, salad). 
A thing not to be neglected is the amount of fluid taken with the food. We have not only to consider the water taken as such, or in the form of soup or tea, but also the water contained in most of our other food. For instance, potatoes or meat contain about 75 per cent. of water, and of the foods like carbohydrates, a part is chemically water; even the fats form water in the body on combustion. The water output equals about 95 per cent. of an average diet, so there is only a slight error if we consider the whole weight of the food as water, and compare this "food weight" with the food value in nems.

In the former example of a gruel containing 400 nems we would say in the recipe the milk must be boiled until the total weight is reduced to 200 grams. We had used 260 grams of milk, 16 of flour, and 10 of sugar, total 286 grams; if 86 grams of water are evaporated out of the milk, the remaining 200 grams will contain 400 nems, or 1 gram contains 2 nems. We call such a composition double strength food; in the same way we can make triple strength food, which contains three times the nutritive amount of milk; we call halfstrength food a composition which contains only $\mathbf{5 0}$ nems in 100 grams.

This is important, especially for babies, for whom we have to provide the necessary water, while at the same time we must not give too great a volume as food. If we give too much water, the baby is not able to drink as much food values as we wish it to drink, 
and if we give too little water, the metabolism becomes disordered. For most children we use about $1.5 \mathrm{nem}$ in a weight of 1 gram. We never exceed a concentration of three times that of milk ( 3 nems in 1 gram) and rarely go below the concentration of milk (1 nem in 1 gram).

Finally, we have to consider the question of fats. From practical experience I make it a rule to order not less than 10 and not more than 20 per cent. of fats, like butter, lard, or oil. But there is no danger from giving under the minimum of 10 per cent., as there would be with the proteins. The fats, as far as they are used as combustibles, can be fully substituted by carbohydrates. The small amount of fat necessary to convey the fat-soluble vitamin can, to my mind, be disregarded in practical feeding in normal times when you are able to give a mixed diet. I have been misunderstood often in my views regarding fat. I never advocated a diet free from fats, but only that a substitution was possible if the conditions of the market made it necessary. At the beginning of the war we had in Austria-Hungary, as a sugar exporting country, a surplus of beet sugar, and, as we were a fat importing country, we soon grew short of fats. We had, therefore, to make the best of the sugar, and I can show that children were able to consume large amounts of sugar as a part of their diet without getting loose bowels or toothache. One has, when giving a large amount of sugar, to be careful to give enough protein in the form of meats, cheese, or milk. 


\section{FEEDING IN THE FIRST YEAR OF LIFE}

You will recall that in a previous chapter we said that we began our work in practice by watching the spontaneous intake of a great many individuals over long periods, and that we compared that intake with the nutritional surface expressed by the square of the sitting height. I did not, however, mention that the standard of the intake was the "hektonem." In this way we secured sufficient data to answer the question of how many "decinems" a person ingests per square centimeter absorbing surface as calculated from the sitting height, or to use a brief expression, how many "decinemsiquas" he ingests.

To explain the term "decinemsiqua" we may take the following example: A child of $50 \mathrm{~cm}$. sitting height takes 1250 nems in his daily diet. We call the square of the sitting height siqua. The daily intake of 1250 nems equals 5 decinems multiplied by siqua or, briefly, 5 decinemsiquas.

$$
\frac{\text { intake }}{\text { siqua }}=\frac{1250 \mathrm{nems}}{50 \times 50}=\frac{1250}{2500}=0.5 \mathrm{nem}=5 \text { decinems }
$$

1250 nems (daily intake) $=5$ decinems $\times 2500$ (siqua) $=1250$ (daily intake)

By registering the weight of the body daily we could observe whether the amount the child ingested 
was sufficient to maintain his weight, or whether he gained, and how much. In drawing conclusions we did not make use of arithmetical averages, but we put down a point for each observation and then drew lines through these points. We registered a point weekly that corresponded to the change in weight (abscissa) and to the average daily intake for the week in decinemsiquas (ordinate). Having registered the records of a large number of children, a graph was constructed by drawing a line through the field of all the points recorded. This method prevented us from being too much influenced by various abnormalities.

The most extensive study was made in nurslings and especially in newborn children (Vol. II, pages 263 to 270). The results of the experiments led us to very simple practical rules.

We distinguish four standard amounts in quantitative feeding-the maximum, the minimum, the æquum, and the optimum. The maximum is the quantity of food that a normal human being can digest within twenty-four hours without impairing his health and without overtaxing his alimentary canal. This maximum is about 1 nem or 10 decinems per square centimeter of the square of the sitting height. The maximum, we will say, is then about 10 decinemsiquas. Most persons left to themselves never attain that limit except in extraordinary circumstances, as, for instance, after several days of fasting. The minimum is the combustible amount necessary to keep the 
human machine going and to maintain the body weight in a condition of no muscular work except that of chewing and digesting. It is the amount that maintains the person in weight if he lies in bed all the time. This amount is required chiefly for the work of the heart and lungs and for that of the large glands (liver, pancreas, etc.). This minimum corresponds to about 3 decinemsiquas. The aquum is the amount required to maintain weight under a given condition of activity. Thus, approximately 1 decinemsiqua more than the minimum is required when a man works at an occupation that is entirely sedentary instead of lying in bed. If he does some walking besides sitting at his desk he needs 2 decinemsiquas in addition to the minimum, or 5 decinemsiquas altogether. If he exercises vigorously or does manual labor he needs additional food-stuffs; for a very hard worker the æquum may become identical with the maximum, for he then does all the work possible with the intestinal equipment he has. Such a man becomes a machine for work just as does a horse or ox. On a well-organized farm these animals are run at full speed, eating their maximum, and doing just as much work as possible without loss of weight. The optimum, finally, is a conception which includes a judgment; it is the amount of food that should be used by a given person. In a case of heart disease this may be identical with the minimum if we desire to keep the patient in bed as quiet as possi- 
ble and doing as little digestive work as possible. In most normal adults the optimum is identical with the æquum, for our object is simply to maintain the weight under their condition of work. But there are certain fat or thin adults whose weight we desire to change. In such cases the optimum will be 1 or 2 decinem less or 1 or 2 decinem more than the æquum. In children the optimum is practically always larger than the æquum, as we wish them to grow; hence, we add at least 1 decinemsiqua to the æquum. The full amount then provides not only for growth in length but also for growth in fat and muscle.

Let us take an example: A boy of eleven years with a sitting height of $70 \mathrm{~cm}$. has a nutrition surface of 70 by $70=4900 \mathrm{~cm}$. The maximum that he could digest would be 10 decinems per square centimeter or 4900 nems. The minimum, if he stays in bed without moving at all (for a healthy boy practically impossible), would be 3 decinemsiquas, 4900 by $\frac{3}{10}=1470$ nems. Though he sits still in school for some hours he is likely to be very active during the rest of the day. We give him, therefore, 3 decinemsiquas more than the minimum in order to maintain his weight; that is, 6 dnsq. per day. But we desire not only to maintain his weight but also to provide for growth and gain in fat and muscle, so we give him say 1 dnsq. more, or 7 dnsq. $\left(\frac{7}{10}\right.$ by $\left.4900=3360\right)$ in all as an optimum.

How should the child take this amount? We must take into account not simply the daily intake, but 
also the distribution of the daily feedings. The food is best utilized when given at regular intervals in equal daily amounts. The advantages of such regular feedings have been known by farmers for a long time. They used to feed their milch cows the same amount three times a day. In children the smaller they are, the less are they able to take large amounts at one time. We have, therefore, to give them many meals in order to make them ingest the necessary amount of food. Rules have to be laid down, therefore, for the division of the optimum amount into constituent meals. In a newborn baby we begin with eight feedings at intervals of three hours-midnight, 3,6 , 9 A. M., midday, 3, 6, 9 P. M. When the baby is a few days old we leave out the midnight meal in order to give the child a longer sleep and to allow the mother more rest. After a fortnight we omit the feeding at 3 A. M., and then only six feedings remain between 6 A. M. and 9 P. M., with the same intervals of three hours. This rule stands for the whole of the first year of life. In the second year we omit the feeding at 9 P. M. and continue throughout the rest of childhood to give five feedings - three main meals, morning, midday, and evening, and two small meals in the middle of the forenoon and afternoon respectively. For adults only three main meals are necessary. The exact times chosen are less important than the observance of intervals between meals. Thus, if we give breakfast at 7.30 instead of at 6 A. M., we may postpone each 


\section{THE PIRQUET SYSTEM OF NUTRITION}

feeding in the whole schedule for an hour and a half. The noon meal could then come at 1.30 and the evening meal at 7.30.

Let us return to the feeding of the nursling or the newborn baby. Six hours after delivery we put the child to the breast, and from that time, at intervals of three hours, we try to keep the child breast fed, and for some days we watch the intake of milk by weighing the child before and after feeding. If the breast milk is sufficient we leave the child to his instinct and control only the number of feedings and the intervals as mentioned. If the mother's milk is not sufficient, or if, for one reason or another, the mother is not allowed to feed the baby, we make use of one of the following substitutes:

As mentioned in the last lecture, every composition which has the same combustible value as human milk we call single strength nutriment (nutrimentum simplex). We use the prefix $S i$ to indicate this order. An example is Sibo, where bo stands for bovinum (bovin origin): "Sibo" = Lac simplex bovinum. This food contains 200 nems in $\mathbf{2 0 0}$ grams and is composed thus:

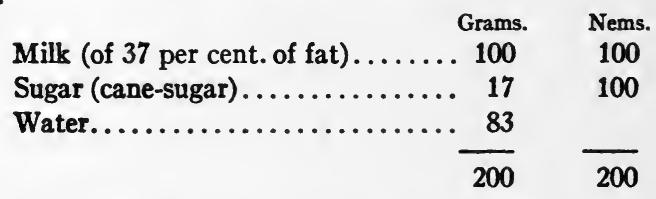

If the children are very apt to vomit, they generally do better if we give very little fluid; we therefore 
have to give the food in higher concentration. We use in these cases a double nutriment: Lac duplex bovinum, or "dubo."

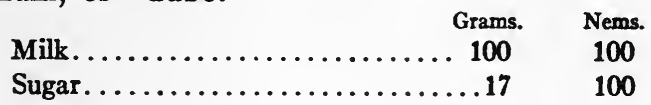

These 117 grams are reduced by boiling to 100 grams of weight and contain 200 nems. Each gram, therefore, contains 2 nems.

Oftener we use a medium between simple and double nutriment called "sesquibo" from the Latin word for one and a half.

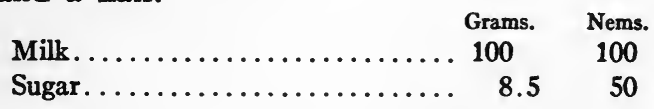

This preparation is reduced by boiling to 100 grams and contains 150 nems.

The amount of food allotted depends on the sitting height of the baby. If, for instance, a child of two months of age has a sitting height of $35 \mathrm{~cm}$., the formula for maximum food allowance would be

$$
\frac{10}{10} \times \text { Siqua }=35 \times 35=1225 \text { nems. }
$$

The optimum food allowance is composed of 3 dnsq. for minimum requirements, 1 for body movements, 1 for growth in length, and 1 for increase in weight, totalling 6 dsnq. For a whole day's ration $1225 \times \frac{6}{10}$ would be required; for each of the six equal feedings 
$1225 \times \frac{1}{10}$ or 122.5 nems, roughly 120 nems. Of "sibo" the child would have to take 120 grams, of "dubo" only 60 grams, and of "sesquibo" 80 grams at each feeding.

In the middle of the first year of life we begin to substitute more solid food for milk at the noon meal. The first semisolid is a gruel of milk, sugar, and flour, in the form of double nutriment, the composition of which I gave in the last lecture.

At nine months the child is taught to eat vegetables at midday. The gruel is given at 6 P. M. The following is an example of mashed potatoes prepared as single strength nutriment:

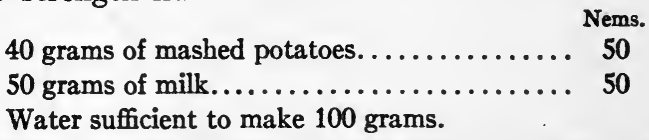

(A little salt is added to accustom the baby to the salty taste.)

From now on every month some new thing is introduced, such as different vegetables, white bread soaked in milk, biscuits, etc. The breast meals are one by one replaced by other feedings in such a way that at twelve months the child is wholly weaned. During the whole second year the education of the child to take different food-stuffs continues. We call this process "the nutrition school." The baby is taught at this very early age to eat small quantities of almost everything appropriate for the child-bread with butter, jam, eggs, and the last thing, at twenty-four months, is a very small quantity of meat. 
To avoid the danger of getting too small an amount of "fat-soluble vitamin" the babies during the winter season get a teaspoonful of cod-liver oil daily, which is at the same time calculated in the food value of the diet:

1 teaspoonful $=5$ grams of oil $\times$ nem value of $13 \frac{1}{3}=46 \frac{3}{3}$, or approximately $=50$ nems.

The babies are exposed as much as possible to sun and open air. We use for that purpose small balconies put in the windows with southern exposure.

We have not sufficient time here to discuss the treatment of premature birth and malnutrition. Let me say only that it is done on exactly the same principles. In very weak premature babies we begin with one extra feeding between the intervals of three hours; that is, we feed them sixteen times a day at intervals of one and a half hours. In malnutrition we lay great stress on the exact registration of stools and vomiting. There are so many cases where an apparent malnutrition is caused only by the fact that the baby vomits a good part of the day's requirements. A baby who vomits and has at the same time a normal stool or one small in quantity, is not to be considered as having "catarrh of stomach," for this kind of vomiting is a more or less nervous habit. Nothing could be worse than to dilute the food for such a baby; on the contrary, the necessary amount of food should be given in a more concentrated form, either as a fluid of "double 


\section{THE PIRQUET SYSTEM OF NUTRITION}

strength nutriment" (dubo), or as a gruel. Losses by vomiting have to be substituted by giving additional food. The calculations are, of course, based on the square of the sitting height.

Diarrhea in babies arises from different causes; in these cases we usually give a water diet for twelve hours, then proceed to the minimum, and slowly go up to the optimum.

Barlow's disease (infantile scurvy), which we saw very rarely before the war, was very frequent during and after, probably as an indirect effect of Austria being cut off from her coal regions. This, of course, seems to be a very remote cause, but coal is necessary to produce artificial ice to cool the milk. When the farmer is without ice he is tempted to use various thermic and chemical devices to keep the milk from souring, and in this way the vitamins are destroyed.

As to rickets, the effect of the war conditions is not so clear. Vienna had always a large amount of rickets, and although most of the physicians in child practice got the impression that they saw a much greater amount of severe rickets during and after the war, statistical proof of this has not been given. Cases of osteomalacia as a consequence of hunger were very frequent in Vienna, mostly in 1919, but not among children.

Work on rachitis in America and England in recent years, and especially the investigations carried out at the University Kinderklinik in Vienna 1921-22 by 


\section{FEEDING IN THE FIRST YEAR OF LIFE 45}

Chick, Dalyell, and Wimberger, have thrown much light on the etiology of rickets, and seem to make the infection theory of its origin superfluous. Present knowledge indicates that the disease results from the combined effect of deficiency in the diet of a specific food constituent (vitamin) and lack of direct sunlight. The old practical rule of fighting rickets by "Licht, Luft, Leberthrahn"-air, light, cod-liver oil-finds a scientific explanation on this basis.

In infant feeding in general, the important changes introduced by this system of nutrition are that the food given has a much higher energy value than has usually been allotted for infants, and that food is given in a much more concentrated form than has been used previously. The excellent results obtained by Schick with his special "Dubo" feeding are likely to have a wide influence on existing pediatric methods. 


\section{NUTRITIONAL TREATMENT OF TUBERCU-}

\section{LOSIS}

WE consider tuberculosis a nutritional disease in the sense that the germs of tuberculosis, which are contained in the body of practically every adult inhabitant of a city, are not allowed to spread and to overwhelm the organism so long as this is in a good state of nutrition. We may say that the power of the cells to produce antibodies depends on a certain excess of food. We have no specific food, no certain chemical substance, which protects against tuberculosis, but we know that good appetite for various kinds of food and satisfaction of this appetite by ample meals is the best preventive and the best cure.

In my opinion, all the cures which in the course of time have been advised for tuberculosis culminate in the therapy of feeding. The patients are sent now to the seashore, now to the mountains, now to the desert, now into a warm valley; all these tuberculosis resorts have in common only the condition that the patients receive good care and, under the influence of change of scene and freedom from home worries, begin to eat. The rest cure in these tuberculosis resorts effects a conservation of energy, while exposure to 
sunshine and fresh air stimulates the appetite and allows an increase of metabolism. Change of location and numerous psychic stimulants may be dispensed with if a definite amount of food is prescribed and if the patients are ordered to take an open-air cure combined with suitable rest intervals. The large sanatorium ward for 100 children on the roof of my clinic in the midst of Vienna, a city so notorious for tuberculosis, furnishes a proof of my assertion. The children remain there from one-half to one year or more. They are in the open air summer and winter, night and day, clad in the daytime to suit the temperature and well covered at night. The children soon become accustomed to living in the open. Only during the cold winter nights must the little ones be provided with hot-water bottles. The children are indoors only when washing or bathing, at meals, and at school, in all about four hours of the twenty-four. In summer school is held also in the open air. The most important function of the day is eating, for food is given as a medicine against tuberculosis, not a certain quality of food, but a certain qualtity.

How do we proceed to prescribe this food? Let us first consider a patient who comes to my out-patient department. Let him be a boy of seven years, pale, emaciated, with some swollen glands, and a history of frequent attacks of colds. The first thing I do is to make a skin test and order a Roentgen photograph. After two days he returns showing a positive test and the 
Roentgen plate shows an enlargement of the bronchial glands. Conditions at home might be favorable for feeding and open-air cure, and I make out an individual prescription for food. I take his height and his weight to determine how many kilograms he is under weight and whether his height corresponds to his age. Then I take his sitting height, and find out, comparing it on a chart with his weight, the pelidisi. The sitting height is $64 \mathrm{~cm}$., the weight, 19 kilograms; the pelidisi, therefore, would be 90 . He is about $3 \mathrm{~kg}$. underweight. His food requirement will consist of 3 decinemsiquas as the basic minimum, with allowance of 2 for muscular movements (partial rest cure), 2 for gain in length and weight, altogether 7 decinemsiquas. For the whole day he gets, therefore, $64 \times 64 \times \frac{7}{10}=$ $2860.2 \mathrm{n}$. We usually put the requirement for purposes of convenience at a round number, viz., the nearest multiple of 500, in this instance, 3000 nems or 30 hektonems per day; of them, 3 hektonems are given at the 9 o'clock meal, 2 in the afternoon at 3 o'clock, and the remaining 25 are divided between the three main meals, 6 A. M., noon, and 6 P. M., which equal 8,9 , and 8 hektonems respectively.

A schedule is made for the time and the amount of the feeding. In case it should be more convenient for the mother to start the day at 7 o'clock, we arrange meals at 7 A. M., 10 A. M., 1 P. M., 4 P. M., and 7 P. M. We give the biggest meal, 9 hektonems, at noon. 


\begin{tabular}{|c|c|c|c|c|c|c|c|c|c|c|}
\hline $\begin{array}{c}\text { Time } \\
\text { of } \\
\text { meal. }\end{array}$ & : & \multicolumn{9}{|c|}{ Amount in grams of each food. } \\
\hline \multirow{2}{*}{$\begin{array}{c}7 \\
\text { A. } \\
\text {. }\end{array}$} & \multirow[t]{2}{*}{8} & $\begin{array}{r}100 \\
\text { milk }\end{array}$ & $\begin{array}{r}100 \\
\text { milk }\end{array}$ & $\begin{array}{c}17 \\
\text { sugar }\end{array}$ & \multirow[t]{2}{*}{$\begin{array}{c}30 \\
\text { bread }\end{array}$} & \multirow{2}{*}{$\begin{array}{c}8.5 \\
\text { but- } \\
\text { ter }\end{array}$} & \multirow[t]{2}{*}{$\begin{array}{c}30 \\
\text { bread }\end{array}$} & \multirow[t]{2}{*}{$\stackrel{20}{\text { hara }}$} & \multirow[t]{2}{*}{$\begin{array}{c}30 \\
\text { jam }\end{array}$} & \\
\hline & & \multicolumn{3}{|c|}{$\begin{array}{l}300 \text { c.c. water and } \\
\text { coffee }\end{array}$} & & & & & & \\
\hline $\begin{array}{c}10 \\
\text { A. M. }\end{array}$ & 3 & $\begin{array}{c}100 \\
\text { milk }\end{array}$ & $\begin{array}{c}30 \\
\text { bread }\end{array}$ & $\begin{array}{c}40 \\
\text { (one) } \\
\text { egg }\end{array}$ & & & & & & \\
\hline \multirow[t]{2}{*}{ P. 1 . } & \multirow[t]{2}{*}{9} & $\begin{array}{c}20 \\
\text { flour }\end{array}$ & $\begin{array}{l}7.5 \\
\text { fat } \\
\end{array}$ & \multirow[t]{2}{*}{$\begin{array}{c}40 \\
\text { meat }\end{array}$} & \multirow[t]{2}{*}{$\begin{array}{c}40 \\
\text { meat }\end{array}$} & \multirow{2}{*}{$\begin{array}{c}80 \\
\text { pota- } \\
\text { toes }\end{array}$} & \multirow{2}{*}{$\begin{array}{c}50 \\
\text { green } \\
\text { peas, } \\
4 \text { but- } \\
\text { ter, } \\
\text { and } \\
46 \\
\text { water }\end{array}$} & \multirow[t]{2}{*}{$\begin{array}{c}30 \\
\text { bread }\end{array}$} & \multirow[t]{2}{*}{$\begin{array}{c}20 \\
\text { cheese }\end{array}$} & \multirow[t]{2}{*}{$\begin{array}{l}150 \\
\text { apple }\end{array}$} \\
\hline & & 200 & soup & & & & & & & \\
\hline $\begin{array}{c}4 \\
\text { P. } \mathbf{x} \text {. }\end{array}$ & 2 & $\begin{array}{r}100 \\
\text { milk }\end{array}$ & $\stackrel{20}{\text { biscuit }}$ & & & & & & & \\
\hline \multirow[t]{2}{*}{$\begin{array}{c}7 \\
\text { P. } \\
\text {. }\end{array}$} & 8 & flour & flour & flour & $\begin{array}{l}100 \\
\text { milk }\end{array}$ & $\begin{array}{c}17 \\
\text { sugar }\end{array}$ & \multirow[t]{2}{*}{$\begin{array}{l}30 \\
\text { bread }\end{array}$} & \multirow{2}{*}{$\begin{array}{c}8.5 \\
\text { but- } \\
\text { ter }\end{array}$} & \multirow[t]{2}{*}{$\stackrel{20}{\text { honey }}$} & \\
\hline & & \multicolumn{5}{|c|}{200 , baked after recipe } & & & & \\
\hline
\end{tabular}

This gives an idea how a day has to be arranged. There is a book of recipes where the mother finds variation for eight different days (System der Ernährung, Vol. III).

In the same schedule we take into account the protein. We count the dekanems of protein contained in every hektonem. 


\section{THE PIRQUET SYSTEM OF NUTRITION}

Dekanems of Protein Contained in Every Hektonem of Food, see p. 31.

\begin{tabular}{|c|c|c|c|c|c|c|c|c|c|}
\hline$\stackrel{2}{2}$ & $\underset{\text { milk }}{2}$ & $\begin{array}{c}0 \\
\text { sugar }\end{array}$ & $\begin{array}{c}1 \\
\text { bread }\end{array}$ & $\begin{array}{c}0 \\
\text { butter }\end{array}$ & $\stackrel{1}{\text { bread }}$ & $\begin{array}{c}3 \\
\text { ham }\end{array}$ & \multicolumn{2}{|c|}{$\begin{array}{c}0 \\
\text { jam }\end{array}$} & $=9$ \\
\hline milk & $\stackrel{1}{\text { bread }}$ & $\begin{array}{c}3 \\
\text { egg }\end{array}$ & & & & & & & $=6$ \\
\hline flour & fat & $\begin{array}{c}4 \\
\text { meat }\end{array}$ & meat & $\begin{array}{c}0.5 \\
\text { potatoes }\end{array}$ & $\begin{array}{c}1 \\
\text { green } \\
\text { peas } \\
\text { and } \\
\text { butter }\end{array}$ & $\begin{array}{c}1 \\
\text { bread }\end{array}$ & cheese & $\begin{array}{c}0.5 \\
\text { apple }\end{array}$ & $=16$ \\
\hline$\underset{\text { milk }}{2}$ & $\begin{array}{c}1 \\
\text { cakes }\end{array}$ & & & & & & & & \\
\hline $\begin{array}{c}1 \\
\text { flour }\end{array}$ & flour & flour & $\underset{\text { milk }}{2}$ & $\begin{array}{c}0 \\
\text { sugar }\end{array}$ & $\begin{array}{c}1 \\
\text { bread }\end{array}$ & $\begin{array}{c}0 \\
\text { butter }\end{array}$ & $\begin{array}{c}0 \\
\text { honey }\end{array}$ & & $=6$ \\
\hline
\end{tabular}

This gives 40 dekanems of protein in 30 hektonems of food; this falls between the minimum of 10 per cent. (30 dekanems) and the maximum of 20 per cent. protein (60 dekanems), and meets, therefore, the requirement.

Water Contained in the Food (Weight of Food, see p. 33).

\begin{tabular}{|c|c|c|c|c|c|c|c|c|c|}
\hline \multicolumn{3}{|c|}{$\begin{array}{l}300 \\
\text { milk and coffee }\end{array}$} & 30 & 8.5 & 30 & 20 & 30 & & \multirow[t]{2}{*}{$\begin{array}{l}\text { Weight, } \\
\text { grams. } \\
418.5\end{array}$} \\
\hline \multirow[t]{2}{*}{100} & 30 & 40 & & & & & & & \\
\hline & $\begin{array}{r}200 \\
\text { soup }\end{array}$ & 40 & 40 & 80 & 100 & 30 & 20 & 150 & 660 \\
\hline \multirow[t]{2}{*}{100} & 20 & & & & & & & & 120 \\
\hline & & 200 & & & 30 & 8.5 & 20 & & 258.5 \\
\hline
\end{tabular}


In order to know the total amount of water we figure the weight of all the dishes on the above form.

The whole day's food is 3000 nems in 1628 grams, therefore about "double strength nutriment," which means rather dry food; 400 grams of water taken at noon or evening will bring this ration on our usual average of water intake.

The feeding cure is combined with a rest cure. The child is left in bed on a porch, in a garden, or on a roof-garden for the first two weeks, then allowed to get up half an hour in the morning and in the afternoon for the next week, and after that is gradually left out of bed for more and more time. The body weight is taken once a week. If in later weeks the gain is not sufficient, we may go to 8 dnsq., adding 3 hektonems, $i$. e., one hektonem to each of the three chief meals, giving, for instance, an additional cake of 20 grams at each main meal.

In an institution where we have many children it would be loss of time to compose a menu for each. We simplify matters then by making

\section{Nutrition Classes}

In a ward containing children affected with slight tuberculusis and convalescents from an acute attack of tuberculosis we put all on a diet of 7 dnsq. and differentiate the amounts, depending on the sitting height of the children. 


\begin{tabular}{|c|c|c|c|c|c|c|c|}
\hline \multirow{2}{*}{$\begin{array}{c}\text { Sitting } \\
\text { beight, } \\
\text { cm. }\end{array}$} & \multirow{2}{*}{$\begin{array}{c}\text { Hn. } \\
\text { per day. }\end{array}$} & \multirow{2}{*}{$\begin{array}{l}\text { Nutrition } \\
\text { class. }\end{array}$} & \multicolumn{5}{|c|}{$\longrightarrow$ Hektonems at each meal } \\
\hline & & & 6 A. ... & 9 A. ห. & Noon & 2 P. $\mathbf{~}$. & 6 P. $x$. \\
\hline $52-56$ & 20 & II & 5 & 3 & 5 & 2 & 5 \\
\hline $57-62$ & 25 & $\mathrm{IIa}$ & 6 & 3 & 7 & 2 & 7 \\
\hline $63-67$ & 30 & III & 8 & 3 & 9 & 2 & 8 \\
\hline $68-73$ & 35 & IIIa & 10 & 3 & 10 & 2 & 10 \\
\hline $74-77$ & 40 & IV & 11 & 3 & 12 & 2 & 12 \\
\hline $78-82$ & 45 & IVa & 13 & 3 & 14 & 2 & 13 \\
\hline $83-86$ & 50 & V & 15 & 3 & 15 & 2 & 15 \\
\hline
\end{tabular}

The children are seated at table according to the class to which they belong, as measured by their nutritional requirements. The food is distributed by means of a graduated dipper for the fluids and a balance for the solids. Bread and cakes are sliced beforehand in hektonem portions. In this way it is very easy to make the children eat all their portions; nothing is allowed to be left. The children have to remain at the table until all is eaten. No remnants are permitted. This results in great economy. No food is turned into garbage. When this system was introduced the man who rented the right of removing the garbage wanted to sue us because he fell short.

The whole day is divided into a schedule which is strictly adhered to:

Hour for rising (the children are required to void). Breakfast.

6.45 Inspection of mouth and throat by the nurse.

7.00 Cleansing of mouth and teeth, washing, combing the hair. 


\section{TREATMENT OF TUBERCULOSIS}

8.00 to 10.00 School in four classes:

(a) Kindergarten.

(b) Lowest class of elementary school.

(c) Second class of elementary school.

(d) All higher classes.

$9.00 \quad$ Second meal.

10.00 to 11.45 Rest cure (in bed on roof garden), medical inspection and treatment.

11.45 Washing the hands.

12.00 Noon meal.

1.00

1.30 to 3.00 Rest cure.

3.00 Afternoon meal.

4.00 to 6.00 Play or school.

5.00 Washing and treatment of skin infections.

6.00 Evening meal.

7.00 Voiding.

7.30 Bed.

Friday is set apart as a bathing day for all the children; there is no school on this day. On Saturday the children are weighed, and a record is made of the weight. This record shows at a glance which children have or have not gained. The reason for failure to gain must be noted in the table-vomiting, infections of the upper respiratory tract, etc.

The increase in weight of malnourished children on such a diet is usually very great in the first month, and after that lessens slowly. A kind of an equilibrium is reached between the intake and the amount of reserve substances in the body. Dr. Therese Zillich made a special study of this question. 


\section{THE PIRQUET SYSTEM OF NUTRITION}

She showed that most of the children fed on 7 dsnq. reached a pelidisi of 94, whereas children fed on 6 dnsq. reached 91.5 , and those fed on only 5 dnsq. did not have a higher average than 89 . From these data we may draw conclusions concerning the amount of food a child has been given if we know his pelidisi. If the children in a boarding school have an average pelidisi of 94 , we may draw the conclusion that the average intake is 7 dnsq. on condition that the bodily exericse is not much different from bodily exercise of the children of our experiments. If, on the other hand, the children have an average of 91 , it means that they received less than 6 dnsq. The 477 children accepted in the year 1919 at Mitterndorf, a country home in connection with my hospital, showed an average of only 89 pelidisi. This figure clearly indicates the defective nutrition during this worst period of Austria's struggle. From May 1, 1917 to May 1, 1918 the average gain of the children on my roof-garden was $11.27 \mathrm{~kg}$.; in later years it was somewhat less due to the fact that the condition of the children was better at the time when they were accepted. A child of school age gains under normal conditions about $2.5 \mathrm{~kg}$. a year; the average gain of our children was, therefore, more than four times the normal gain in weight for healthy children of corresponding age under normal conditions. This enormous increase in gain has its explanation partly in the poor condition of the children at the time of their acceptance. Another factor 
which must be taken into consideration is that the majority of children did not stay the whole year, but left the hospital when they had gained. But the excessive gain shows one thing-that our feeding methods worked well in practice and that, at a minimum of expense, the children gained well in weight. The total average expense per capita in 1917 was 2.54 kronen, or less than 50 cents. Of the allowance of 5 kronen per child we saved about one-half. The diet used was very simple. I do not, as I previously said, believe that any particular food is necessary for the treatment of tuberculosis. The children received meat only once a week. The greater part of the food consisted of flour, milk, potatoes, and sugar. The protein average ran close to 10 per cent. In this last half year we made an extensive experiment concerning fat requirements in the diet. One-half of the children were given a diet rich in fats; the other half was given a diet of the same nutritive value which was poor in fats. The result showed not the slightest difference between the two groups either in respect to the average gain or the progress of the tuberculosis.

For an institution like a tuberculosis sanatorium in which most of the children come from poor families, and especially in a country like Austria where the whole population is impoverished, it is very important to make the hospital diet inexpensive. It may do in an acute illness to "feed up" the child with eggs and white meat. Tuberculosis, however, lasts for 
years. The tenacity for the spread of infection from a tuberculous focus lasts certainly much longer than the duration of the child's stay in the hospital. If we should spoil the child with nice and tasty food, the result would be that he would no longer want the poor food he received at home. In a short time all the gain in weight obtained at the hospital would be lost. We saw hundreds of instances of this among the Austrian children who were taken after the war by Swiss and Dutch friends for a stay of six or eight weeks in the prosperous countries of Switzerland and Holland. On the other hand, children who became accustomed to the simple diet in my hospital and, most important of all, learned to eat everything which was set before them, became "educated eaters" and continued to eat in their homes.

As to the results of our feeding method in tuberculosis, I may say that we are extremely well satisfied. Having proved that method, we gradually forgot about all other methods of cure. We do not use tuberculin treatment any more, though we were very fond of it before. We do not use any other specific medical treatment. Our prognosis in a case of tuberculosis becomes more and more optimistic. We used, for instance, to consider pulmonary tuberculosis in the case of girls between the ages of eleven and fourteen years as almost fatal; now we see many recoveries. Our greatest pride is in the results obtained from treatment of children suffering from 
tuberculoma of the brain. I will call attention especially to the case of one boy who suffered severe epileptic attacks and presented symptoms of cerebral pressure. The diagnosis of a tuberculous brain tumor had been established as far as was possible in the living subject. The treatment was conducted at my clinic from January to November, 1918, and was continued at home by the mother. The treatment resulted in a perfect cure. I saw him on the last occasion in the spring of 1921, when he was healthy and vigorous and mentally perfectly normal. There is no reason why a tubercle in the brain should not be as readily curable as tubercles in other organs which, as we all know, are susceptible to cure. The chief difficulties to overcome in such a case are the tendencies to nausea and vomiting and lack of appetite. These symptoms are controlled only by an exact regulation of the quantity of food, combined with skill and scrupulous exactness in administration of food. 


\section{PROPER FEEDING AS PREVENTIVE MEDICINE}

Up to recent years the science of nutrition has been rather neglected by the clinician. When I was a student I learned a little about calories in the physiology class, but I had no scientific idea about the practice of feeding. Up to now there are only a few places where this latter subject has been attempted. It is an easy thing to teach the fundamental principles about food values and all that, but the chief problem is to make a cook or a grandmother believe in the practice of scientific feeding. It is one thing to prescribe a medicine and another thing to prepare it. We may have some idea how a prescription should be compounded, but most of us would be lost without a pharmacist to do it. The pharmacist gets a scientific training in order to be educated to perform his work with scrupulous accuracy and to understand what he does; and the same should be done with the cook. In Austria nurses have looked down on cooking as an art much inferior to nursing. Since $I$ take my best nurses for superintending the kitchen and since $I$ declare that the kitchen, for me, is more important than the pharmacy, I find a wonderful co-operation. 
Feeding, indeed, is the most valuable thing in the hands of the doctor if you only think of tuberculosis. This is the great disease of childhood. Most of the serious complaints in school age come from it; and we can cure it with proper feeding. Rickets and Barlow's disease have also a close connection with feeding, and the cure of typhoid and dysentery are mostly dependent on quantitative feeding, not to speak of the other tribulations of the first year of age, which, to about 50 per cent., result from improper feeding.

But we are not only curing disease, we are preventing it with the correct feeding. We avoid malnutrition of the baby, we avoid Barlow's disease, and we avoid the serious forms of tuberculosis if we keep the children in a constant good state of nutrition. For this reason proper feeding can be ranked among the best means of preventive medicine.

But in order to make it so effective that real statistical results can be obtained we cannot be satisfied if proper feeding principles be applied to individuals or to a small group of people. We must try to make the science of nutrition a part of the education of the people at large; everybody should know about it, every individual should partake of the privileges of this science.

The science of nutrition is based on quite a number of other sciences. It uses: 
(a) Chemistry, general and analytical chemistry of food-stuffs.

Biochemistry.

Chemical technology.

(b) Botany, systematic and descriptive:

Physiology of plants.

Geography of plants.

(c) Zoölogy.

(d) Minerology.

We have to consider, furthermore,

(e) Comparative science of nutrition.

(f) Physiology of nutrition and most of the other chapters of physiology.

We considered in a former lecture the food-stuffs only according to their nutritive value and according to their content of protein. If we study them we have to bring whatever we use in our kitchen into a systematic order. We distinguish nine groups of food-stuffs and appliances:

1. Milk and cheese.

2. Meat and preparations from meat.

3. Egg and albumen preparations.

4. Fat and seeds containing fat, for instance, linseed.

5. Flour and seeds containing carbohydrates, for instance, wheat.

6. Sugar and fruits.

7. Vegetables (potatoes, beets, green vegetables).

8. Spices. 


\section{FEEDING AS PREVENTIVE MEDICINE 61}

9. Various accessories and utensils of the kitchen, for instance, refrigerator, ovens, etc.

Concerning all the food-stuffs we have to heed the principal data which the sciences above mentioned have brought to our knowledge. There is, I think, also the training of the American dietitian. What we add to it is the calculation in nems.

The housekeeper has to buy-for a family or a larger body in moderate circumstances-the necessary amount of food at a minimum price. If the majority of housekeepers of a country know what is worthwhile buying they will regulate the market and a great saving for the whole community will result. In a poor country like Austria this is very important, as it means that our people will be able to eat more at the same cost. Our people, for instance, have the idea that meat is an extremely valuable thing, and they deprive themselves of other food in order to eat meat. Meat, in fact, is not at all necessary, and, for a densely inhabited country, is very expensive because an animal like a pig needs a great amount of food which could be used for human beings as well. Of 6 units of food consumed as fodder the pig gives back only one single unit in the form of meat or lard. If a poor man eats 6 units in the form of potatoes, he is so vuch better off than eating the one value in the form or reat, and if the majority of the population thinks that way the farmer will sell the potatoes at a greater profit than he could obtain from selling the pig. This, of course, 
does not apply to a country like America, which is overflowing with fodder for animals. You do not know what to do with your surplus of corn, and fat production by the way of the pig is a very sensible thing.

The greatest prevention we are able to exercise through proper feeding is the prevention of stunted growth and muscular weakness. Growth is dependent on two factors: heredity and proper care of the child. In hundreds of instances of daily life children grow taller than their parents if they are well cared for, have always a sufficient amount of proper food, and are given the opportunity for exercise. On the other hand, in a family with tall ancestors, one or the other child may stay small and feeble. If you go into the history of the case you usually find that this child had no appetite, and the parents did not insist on the child's eating because they thought that eating in the absence of appetite did not help. This idea is entirely wrong. The appetite aids digestion. Digestion takes place more rapidly if the appetite is intense, but assimilation also takes place if appetite is lacking, and the combustion in the muscles or the growth in length and in fat tissue take place just as well from a food which has been eaten because of a desire for it as from food taken when all desire is absent. You all know about an instance of this law in feeding geese. The fowls have to digest much more food than is necessary and at the same time they are prevented from running about and dispensing the 
surplus in muscular action. The consequence is that they get very fat.

In rearing animals the farmers have appreciated for a long time all these rules much better than the city people have realized them in the care of their children. The farmers know, for instance, that a long period of food scarcity affects growth so much that the animals are stunted for lifetime. This is the case now with millions of young human beings in Europe. But there is one advantage; the period of growth in man lasts so much longer than in animals, and an undernourishment of one or two years can be overcome in its consequence if we are able to feed amply during the rest of childhood.

One of my assistants, Dr. Kassowitz, made a study of children in a home. All came in in a very poor state of nutrition and their average height was a great deal below the normal for the age of the child. By feeding them quantitatively through six years these children not only became heavier than so-called normal children, but their average height also surpassed the normal.

When American feeding started in Austria the children of fourteen years were several centimeters below the normal in height. We made a special study of several thousand apprentices who received American food. With these additional meals they began to grow again twice as fast as the normal rate of growth for that age; and if we are able to continue having them fed 


\section{THE PIRQUET SYSTEM OF NUTRITION}

they will reach normal size just in time, for after puberty is reached the ability to grow diminishes rapidly.

Feeding as a preventive measure against the effects of food scarcity must be used on a very large scale, and for that, methods of mass feeding must be developed. They include the methods of building and organizing large kitchens, bookkeeping in food values, and various methods of inspection and control. I cannot here go into the details of organizing a kitchen, as this is a science in itself, but I may give you an idea about making a "budget" in terms of food values.

Let us take, for an example, a summer home opened for 600 children. It is a farm with 40 cows. The only food-stuffs available on the place are 20 metric tons (about 4400 pounds) of potatoes and the same amount of green vegetables. Everything else has to be brought from the city. How much will be needed for a stay of two months?

You will have to state your needs. The children on an average of eleven years need 35 hektonems a day. You will need for these children about 60 adults, with 50 hektonems a day. We will need 24,000 hektonems or 2400 kilonems a day. We stay there two months; therefore we will need $2400 \times 60=144,000 \mathrm{kn}$. or 144 tonnenems.

Now we have to figure out how much food we find there and how much we will have to import. A cow yielding an average amount of milk may be figured 
with 10 liters of milk (a liter is about a quart) or 10 kilonems a day. 60 days $\times 10 \mathrm{kn} . \times 40$ cows $=24,000$ kn. Twenty metric tons of potatoes are 20,000 kilograms. A kilogram of potatoes contains 1.25 kilonem.

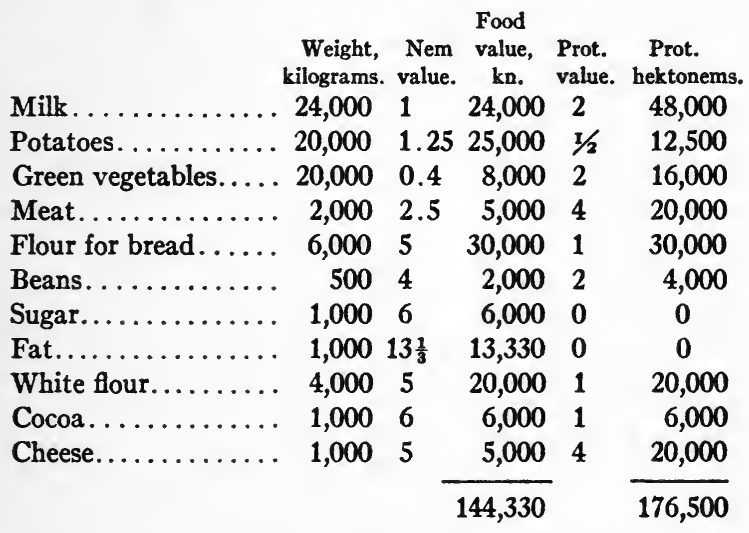

The 144,330 kilonems contain 176,500 hektonems in the form of protein; this is between 10 and 20 per cent., therefore right.

Another kind of a budget is to be made if we get a certain amount of food-stuffs for a given period and have to determine how many people we are able to feed with it.

Let us say that a relief administration would furnish the following consignment for a month for the children of a town: 


\begin{tabular}{|c|c|c|c|}
\hline $\begin{array}{c}\text { Metric } \\
\text { tons. }\end{array}$ & Article. & $\begin{array}{l}\text { Nem value } \\
\text { per gram. }\end{array}$ & $\begin{array}{l}\text { Nem } \\
\text { value of } \\
\text { article in } \\
\text { tonnenems }\end{array}$ \\
\hline 150 & Flour.......... & 5 & 750 \\
\hline 50 & Sweet condensed milk & 5 & 250 \\
\hline 50 & Evaporated milk.. & 2 & 100 \\
\hline 40 & Beans. & 4 & 160 \\
\hline 30 & Cocoa............. & 6 & 180 \\
\hline 30 & Rice........ & 5 & 150 \\
\hline \multirow[t]{2}{*}{30} & Bacon. . & 10 & 300 \\
\hline & & & 1890 \\
\hline
\end{tabular}

The total nem value is 1890 tonnenems. The standard meal for children is one kilonem; this makes $1,890,000$ meals. A month has 25 weekdays; 76,600 children, therefore, could get one meal on every weekday. Accordingly we would have to choose this number of children for the meals.

In this town 184,000 children would have been examined in the pelidisi classification and would have shown the following figures:

Pelidisi............ $89 \quad 90 \quad 91 \quad 92 \quad 93 \quad 94 \quad 95$ and more Children (thousands)... $\begin{array}{lllllll}19 & 24 & 27 & 31 & 28 & 25 & 30\end{array}$

We would take, after the pelidisi examination, the groups 89,90 , and 91 pelidisi, which make 70,000 children; for the rest of the 7600 children we would pick out those from the higher pelidisis by a medical examination called the "sacratama" method. 
Now we would have to plan six different meals for each day of the week out of the given food-stuffs. Each meal must contain 1 kilonem food value, must be appetizing, and must be suitable for the cooking facilities, kettles, and ovens of our kitchens. This means consideration of the dishes which are given in a boiled or in a baked form.

You see how the science of nutrition can be applied to the single individual, to a group of people, as well as to feeding on the largest scale. The knowledge of this science will help humanity to cure individual disease and to prevent the worst plagues of humanity-body weakness and tuberculosis. 


\section{BIBLIOGRAPHY}

Ambrožic, Matija and Rach, Egon: Grundriss der Diätverordnungslehre in der Pädiatrie nach dem Pirquet'schen System. Leipzig and Wien, Franz Deuticke, 1921.

Ambrožiz, M.: Der Nahrungsbedarf beim Myxödem. Ztschr. f. Kdh., 29, 1921, 117.

Aron, Hans: Uber den "Nährwert" und die Bedeutung der Nahrungsfette. Biochem. Ztschr., Bd. 103, 1920, 172.

Behm-Heuberg: Referat über das "Lehrbuch der Volksernährung nach dem Pirquet'schen System" von E. Mayerhofer und C. Pirquet, Arch. f. Kdh., 68, 1921, 491.

British Medical Journal, October 30, 1920, 606: The "Nem" System of Nutrition.

Carter, William: The Pirquet System of Nutrition and its Applicability to American Conditions, Journ. of the Amer. Med. Assoc., vol. 77, No. 20, 1921, 1541.

Chick, Harriette, and Dalyell, J.: Eine Skorbutepidemie unter Kindern im Alter von 6 bis 14 Jahren. Ztschr. f. Kdh., 26, 1920, 257.

Dittrich, Johanna: Speisepläne für kleinere Kinder. in Pirquet, System d. Ernährung, III, p. 129.

Edelstein, F., and Langstein, L.: Das Pirquet'sche System der Ernährung. Berl. Klin. Wchnschr., 1920, 823 and 852.

- Aussprache über den Vortrag über Das Pirquet'sche System der Ernährung. Berl. Klin. Wchnschr., 1920, 715.

Edelstein: Referat über das Lehrbuch der Volksernährung nach dem Pirquet'schen System. Zentralbl. für die ges. Kdh. Bd. 10, 1921, 33. 
Edelstein: Energiehaushalt und Ernährung, Ubbersichts-Referat, Zentralbl. für die ges. Kdh., Bd. 9, 1920, 129.

Faber, Harold K.: Von Pirquet's Feeding System, American Jour. of Dis. of Children, 19, 478.

Germann, A. K.: High Sugar Feeding, Med. Clin. of North America, Vol. 3, No. 6, 1920, 1559.

Gironcoli, U. de: Jl sistema dietetico de Pirquet, La Pediatria: Vol. 30, Fasc. 4, 1922.

Gray, H., and Howard F. Root: Weight Prediction by the Formulæ of Bornhardt, of von Pirquet, and of Dreyer, Boston Med. and Surg. Jour., 185, 28.

Gröer, F. V.: Ernährungsversuche bei infektionskranken Kindern, I. Úber die Durchführung quantitativer Ernährungstherapie der akuten Infektionskrankheiten, Ztschr. f. Kdh., 23, 1919, 125.

Ernährungsversuche bei infektionskranken Kindern. II, Mastkuren bei Kinderruhr, Ztschr. f. Kdh., 23, 1919, 221.

Ernährungsversuche bei infektionskranken Kindern, III, Über die Bemessung der täglichen Nahrungszufuhr bei Infektionskrankheiten, Ztschr. f. Kdh., 23, 1919, 293.

- Rationelle Ernährung der Kinder nach dem System v. Pirquet in einfachen Massenbetrieben, Ztschr. f. Kdh., 18, 1918, 297.

Hamburger, F., and Jellenigg: Die Gelidusimethode zur Feststellung des Ernährungszustandes, Wien. klin. Wchnschr., $1920,1131$.

Hecht, A. F.: Bestimmung des Nemwertes aus dem spezifischen Gewicht, System der Ernährung, IV, Teil, Berlin, Julius Springer, 1920.

Heller, Oskar: Zur Wirkungsweise konzentrierter Säuglingsnahrungen, Monatschr. f. Kdh. 19, 1921, 391.

Heller, R.: Uber den Wert der Indices zur Beurteilung des Ernährungszustandes von Kindern bei Massenuntersuchungen, Wien. med. Wchnschr., 1921, 1415. 


\section{THE PIRQUET SYSTEM OF NUTRITION}

Helmreich, Egon, and Schick, Bela: Utber konzentrierte Ernährung und deren Indikation (besonders im Säuglingsalter).

- Uber konzentrierte Ernährung, II, Mitteilung, Einfluss wechselnder Konzentration auf Körpergewicht und Harnmenge des Säuglings, Ztschr. f. Kdh., 30, 1921, 147.

- Ernährungsstudien beim Neugeborenen, IV, Mitteilung, Ztschr. f. Kdh., 30, 1921, 363.

Hjärne, Urban: Einige Beobachtungen betreffend Körperlänge, Körpergewicht und Ernährungszustand, Acta pædiatrica, Vol. I, fasc. 3, Uppsala.

Hopkins, F. G.: The Huxley Lecture on Recent Advances in

Science in their Relation to Practical Medicine and the Nutritional Requirements of the Body, The Lancet, 1921.

Jde, Toshio: Tryptophanaufnahme und Tryptophanbedarf im Kindesalter, Ztschr. f. Kdh., 31, 1922, 257.

Jelenigg, Karl: Darmlänge und Sitzhöhe, Wien. klin. Wchnschr., 1921, 604.

Kassowitz, Karl: Zur Frage der Beeinflussung der Körperlänge und Körperfülle durch die Ernährung, Ztschr. f. Kdh., 30, 1921, 275.

- Neue Wege der Ernährungsfürsorge, Kalender der österreichischen Volkszeitung, Jahrgang, 1922.

Kleinsasser, E.: Studie über die Ernährungs- und Wachstumsverhältnisse der Tiroler Schuljugend, Mitt. d. Gen. Kommiss. d. amerik. Kinderhilfsaktion, 1921, 125.

Langstein: Pirquet's System der Ernährung, Mediz. Klinik, 1918, 601.

Lendl, Marietta; Anstaltskost, in Pirquet, System d. Ernährung, III, p. 105.

Loewy, A.: Referat über Pirquet's System der Ernährung, Deutsch. med. Wchnschr., 1917, 1433 and 1919, 945 and 1201.

Mayerhofer, Ernst: Ernährungskunde, Wien. klin. Wchnschr., 1919, 1039. 
Mayerhofer, Ernst: Beiträge zur Geschichte der quantitativen Ernährungslehre, Wien. med. Wchnschr., 1902, 1539.

- Das österreichische Hauptkommissariat für die Länder mit Ausnahme von Wien und Niederösterreich, Wien. klin. Wchnschr., 1921, 324.

- Bemerkungen zur Mitteilung von R. Heller über den Wert der Indices zur Beurteilung des Ernährungszustandes von Kindern bei Massenuntersuchungen, Wien. med. Wchnschr., 1921, 1598.

Therapie der Kinderkrankheiten in Landesmann, Therapie an den Wiener Kliniken, Wien Deuticke, 1922.

Medizinische Studie über die amerikanische Kinderhilfsaktion in Osterreich, Mitteilungen d. Gen. Kommiss. d. amerik. Kinderhilfsaktion, Jg., 1920, S. 5.

Los medios auxiliares naturales en la lucha contra la tuberkulosis de la infancia, Revista médica de Hamburgo, 1921, Nos. 11 and 12.

Küche und Volksernährung, Kalender der Volkszeitung, 1921, Seite 102-104. (Wien., printed and published by "Steyrermühl.")

Mayerhofer, E., and Cl. Pirquet: The American Relief Administration European Children's Fund in Austria. Printed by J. Weiner, Vienna. Edited by the General-Commissariat. Mayerhofer, E., and Pirquet, C.: Lehrbuch der Volksernährung nach dem Pirquet'schen System, Wien-Berlin, Urban and Schwarzenberg, 1920.

Mayerhofer, E., and Reischl, Friedrich: "Ernährungskunde," Osterr. Almanach für Ernährung, 1921-1922. M. Salzer, Wien., 1921.

Merill, Th., and $\mathrm{H}$. Violle: Les grandes formules modernes de la nutrition, leur applications pratiques, Presse méd., Jg. 29, No. 94, S. 931, 1921.

Meyer, F. L.: Referat über C. Pirquet, System der Ernährung, Deutsche med. Wchnschr., 1921, 575. 


\section{THE PIRQUET SYSTEM OF NUTRITION}

Miari, Rosa: Allgemeine Küche, Pirquet, System d. Ernährung, III, p. 32.

- Speisepläne für ältere Kinder und Erwachsene, Pirquet, System d. Ernährung, III, p. 137.

Niemann: Referat über E. Mayerhofer und C. Pirquet, Lehrbuch der Volksernährung nach dem Pirquet'schen System, Deutsche. med. Wchnschr., 1920, 1377.

Nobel, E.: Grundzüge des Pirquet'schen Ernährungssystems; Wien und Leipzig, Josef Safar, Ubersetzungen: Kroatisch, Polnisch, Englisch, Russisch, Tschechisch.

-_ Praktische Durchführung des Ernährungsystems in einem Militarspitale, Pirquet, System d. Ernährung, II, p. 390.

Über den Wasserhaushalt des kindlichen Organismus, die Grenzen der Wasserentziehung und ihre systematische Anwendung bei pathologischen Zuständen, Ztschr. f. Kdh., 22, 1919, i.

__ Zur Aufklärung über das Nemsystem, Wien. klin. Wchnschr., 1920, 965.

__ Einiges über die amerikanische Kinderausspeisung in Wien und Niederösterreich, Wien. klin. Wchnschr., 1921, 325.

__ Organisatorische Aufgaben bei Massenspeisungen von Kindern. In Mayerhofer-Pirquet.

- Grundzüge des Nemsystems. In Mayerhofer-Pirquet.

—_ Säuglingsernährung, Wien. med. Wchnschr., 17/18, 1922.

_- Schülerspeisung in Wien. Wien, Safar, 1921.

- Schülerspeisung in den Städten und kleineren Orten Niederösterreichs, Wien, Safar, 1921.

_- Zur Barlowfrage Bedeutung der Hitzewirkung auf die Vitamine, Beitrag zur Frage der Nahrungskonzentration, Ztschr. für Kdh., 28, Heft 5/6, 1921.

_ Beitrag zur Barlowfrage, Wien. klin. Wchnschr., 1920/52. Nobel, E.: Praktische Durchführung des Ernährungssystems von Pirquet in einem Militärspitale, Wien. med. Wchnschr., 1917, No. 51 . 
Noble, E., and Toshio Jde.: Beitrag zur konzentrierten Ernährung des Säuglings. Ztschr. für. Kdh., 1922.

Nobel, E., and Wagner, R.: Trockenmilch in der Kinderernährung, Ztschr. f. Kdh., 30, $1921,291$.

Richtlinien zur Massenspeisung der Kinder, Wien. med. Wchnschr., 1920, 1594.

Panzer, Paula: Die graphische Darstellung des Appetites und der Bewegung der Säuglinge auf den Übersichtskurven, Ztschr. f. Kdh., 29, 1921, 90.

- Ernährungsschule für Säuglinge in Pirquet, System d. Ernährung, III, p. 120.

Pfaundler, M.: Úber die Indices der Körperfülle und über "Unterernährung," Ztschr. f. Kdh., 29, 1921, 217.

Pirquet, Clemens Freiherr von: System der Ernährung, Erster Teil, Berlin, Julius Springer, 1917.

- System der Ernährung, Zweiter Teil, Mit Beiträgen von Prof. Dr. B. Schick, Dr. E. Nobel und Dr. F. v. Gröer, Berlin, Julius Springer, 1919.

- System der Ernährung, Dritter Teil: Nemküche. Mit Beiträgen von Schwester Johanna Dittrich, Schwester Marietta Lendl, Frau Rosa Miari und Schwester Paula Panzer, Berlin, Julius Springer, 1919.

- System der Ernährung, Vierter Teil, Mit Beiträgen von Prof. F. v. Gröer, Doz. Dr. A. Hecht, Doz. Dr. E. Nobel, Prof. Dr. B. Schick, Dr. R. Wagner und Dr. Th. Zillich, Berlin, Julius Springer, 1920.

—_ Sitzhöhe und Körpergewicht, Ztschr. f. Kdh., 14, 1916, 211.

_- Die Milch als Nahrungseinheit, Ztschr. f. Kdh., 14, 1916, 197.

- Die einzelnen Nahrungsstoffe, Ztschr. f. Kdh., 14, 1916, 449.

__ Ernährung nach der Darmfläche, Ztschr. f. Kdh., 15, 1917, 100. 
Pirquet, Clemens Freiherr von: Tafel zur Ernährung des Menschen, Ztschr. f. Kdh., 15, 1917, 117.

Tafeln für den Einkauf von Nahrungsbrennstoff und Nahrungseiweiss, Ztschr. f. Kdh., 15, 1917, 136.

_ Körpergewicht und Darmfläche, Ztschr. f. Kdh., 15, 1917, 213.

— Der Nährwert des Fleisches, Ztschr. f. Kdh., 16, 1917, 241.

_ Utber den Nahrungswert der Milch und seine Bestimmung aus der Trockensubstanz, Ztschr. f. Kdh., 17, 1918, 114.

- Uber den Nahrungswert der Kartoffel und seine Bestimmung aus der Trockensubstanz, Ztschr. f. Kdh., 17, 1918, 145.

- Berechnung des Nemwertes von Gemüse, Obst und Getränken aus der. Trockensubstanz, Ztschr. f. Kdh., 18, 1918, 167.

- Uber den Nemwert von Pflanzensamen, Mehl, Brot und Teigwaren, Ztschr. f. Kdh., 18, 1918, 185.

- Bestimmung des Nemwertes der Butter aus der Trockensubstanz, Ztschr. f. Kdh., 18, 1918, 201.

- Der Nemwert von Rahm, Magermilch, Buttermilch, Molken, Käse, Würsten, Fleisch- und Fisch-Dauerwaren, Ztschr. f. Kdh., 18, 1918, 207.

- Bestimmung des Ernährungszustandes, Ztschr. f. Kdh., 18, 1918, 220.

_ Die Aufgaben der Küche, Ztschr. f. Kdh., 18, 1918, 249.

- Der Nemwert von Fettgewebe und von ganzen Schlachttieren, Ztschr. f. Kdh., 18, 1918, 270.

- Über Nahrungsbedarf und Gewichtszunahme der Säuglinge, Ztschr. f. Kdh., 18, 1918, 274.

— Der Begriff “Aequum," Ztschr. f. Kdh., 30, 1921, 145.

- System der Ernährung, München. med. Wchnschr., 1917, 515.

- Die amerikanische Schulausspeisung in Osterreich, Wien. klin. Wchnschr., 1921, 323.

- Die amerikanische Kinderhilfsaktion in Usterreich, Wien. med. Wchnschr., 1920, 854 and 907. 
Pirquet, Clemens Freiherr von: Quantitative Ernährungstherapie, Ther. Mh., 1917, Okt.

Die amerikanische Kinderhilfsaktion in Osterreich, Österr. Rundschau, Bd. lxiii, Heft 6 (1920).

Nutritional Treatment of Tuberculosis, New York Med. Journal, Feb. 1, 1922.

Pirquet, Clemens and Mayerhofer, Ernst: The American Relief Administration European Children's Fund in Austria. Printed by J. Weiner, Vienna. Edited by the General-Commissariat.

- Lehrbuch der Volksernährung. Wien Berlin Urban u. Schwarzenberg, 1920.

__ and E. Wölfel: Milchsalze, Ztschr. f. Kdh., 17, 1918, 141. Progulski, Stanislaw: O rokowaniu i leczeniu teżca noworodk6w, Polska Gazeta Lekarska, No. 17, 1922.

Rach, E.: Die Milch als Vergleichseinheit für die Nährwertkonzentration der Nahrungsmittel, München. med. Wchnschr., 1919, 1196.

Reischl, Friedrich: "Das Pirquet'sche Ernährungssystem," in "Wiens Kinder und Amerika," Seite 120-140, Gerlach and Wiedling, 1919.

"Die Ernährung nach dem Nem-System," Populäre und sehr kurze Darstellung, Krakauer Kalender, 1921. M. Salzer, 1920.

"Mitteilungen der Amerik. Kinderhilfsaktion (American Relief Administration"), Bd. I, II, III, Generalkommissariat der A. K. H. A. Printed by M. Salzer.

Reischl, Freidrich, und Mayerhofer, Ernst: "Ernährungskunde,"

Ost. Almanach f. Ernährung, 1921-1922. M. Salzer, 1921.

Rosenfeld, S.: Zur Aufklärung über das Nemsystem. (Zu Nobels Aufsatz in der Wien. Klin. Wchnschr., 1920, No. 44), Wien. klin. Wchnschr., 1920, 1051.

Schick, Bela: Ernährungsstudien beim Neugeborenen, Ztschr. f. Kdh., 17, 1918, 1. s. Pirquet, System der Ernährung, II, p. 148. 
Schick, Bela: Ernährungsstudien beim Neugeborenen, II, Mitteilung, Ztschr. f. Kdh., 22, 1919, 195.

- Ernährungsstudien beim Neugeborenen, III, Mitteilung, Ztschr. f. Kdh., 27, 1921, 57.

- und Helmreich Egon: Ernährungsstudien beim Neugeborenen, IV, Mitteilung, Ztschr. f. Kdh., 30, 1921, 363.

_- Der Nährwertbedarf der stillenden Frau, Ztschr. f. Kdh., 21, 1919, 284.

- Der Nährwertbedarf der Frau im letzten Drittel der Schwangerschaft, Ztschr. f. Kdh., 23, 1919, 26.

- Das Pirquet'sche System der Ernährung und seine Gegner, Ztschr. f. Kdh., 28, 1921, 62.

__ Das Pirquet'sche System der Ernährung; für Ärzte und gebildete Laien, Berlin, Julius Springer.

- Darmlänge und Sitzhöhe, Bemerkungen zur Publikation von Dr. Karl Jellenigg in der Wien. klin. Wchnschr., No. 50, 1921; Wien. klin. Wchnschr., 1922, 58.

Stoeltzner, W.: Energiequotient, Nemsystem, Bedarfsfläche, München. med. Wchnschr., 1921, 1518.

Terner, Karl: Das Wachstum und die Länge des Darmkanals im

Kindesalter, Verhältnis der Darmlänge zur Sitzhöhe, Ztschr. f. Kdh., 21, 1919, 408.

Wagner, Richard: Die zahlenmässige Beurteilung des Ernährungszustandes durch Indices, Ztschr. f. Kdh., 28, 1921, 38.

- Korrekturtabelle für Kuhmilch, in Pirquet, System der Ernährung, IV, Teil, p. 10.

- Trockensubstanzbestimmungen in fertigen Speisen, in Pirquet, System d. Ernährung, p. 12.

- Fettbestimmungen in fertigen Speisen, in Pirquet, System der Ernährung, IV, Teil, p. 22.

- Praktische Handhabung der Kontrolle des Backprozesses mittels der Trockensubstanzbestimmung des Brotes, in Pirquet System der Ernährung, IV, Teil, p. 28.

Walgren, Arvid: On Pirquet's Nutritionslära, Upsala Lukareförenings förhandlingar, Bd. xxvii, H. 1-2, 1922, 53. 
Wimberger, Hans: Beziehung zwischen Nahrungskonzentration und Blutbeschaffenheit, Ztschr. f. Kdh., 25, 1920, 64.

- Eineiige Zwillinge, Ztschr. f. Kdh., 31, 1921, 216.

Zillich, Therese: Nahrungsmenge und Ernährungszustand in Pirquet System der Ernährung, IV, Teil, Berlin. Julius Springer, 1920. 



\section{NEM VALUE OF THE PRINCIPAL FOOD-STUFFS}

The table contains the following references:

1. Nem in $1 \mathrm{gram}$. The number of nems contained as an average in $1 \mathrm{gram}$ of the article in question.

2. Hektonem weight. The number of grams of each article of food contained in 1 hektonem (100 nems) food value.

3. Protein value. Approximate amount of dekanems protein in one hektonem of the article.

4. Formula. For the purpose of a more exact determination of food values it is necessary to make a simple chemical examination of the article, determining the dry substance (T), the content in fats (F), and ashes (A). The details of this examination are found in System der Ernährung, vol. iv.

\begin{tabular}{|c|c|c|c|c|}
\hline & $\begin{array}{c}\underset{\text { Nem }}{\text { in } 1} \\
\text { gram. }\end{array}$ & $\begin{array}{l}\text { Hekto- } \\
\text { nem } \\
\text { weight, } \\
\text { grams. }\end{array}$ & $\begin{array}{c}\text { Protein } \\
\text { value. }\end{array}$ & Formulas. \\
\hline 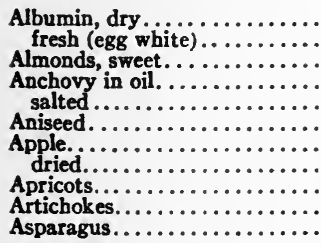 & $\begin{array}{l}5 \\
0.67 \\
8 \\
3 \\
1.5 \\
3.3 \\
0.67 \\
3.3 \\
0.67 \\
0.25\end{array}$ & $\begin{array}{c}20 \\
150 \\
12.5 \\
33 \\
67 \\
30 \\
150 \\
30 \\
150 \\
\dddot{900}\end{array}$ & $\begin{array}{l}9 \\
9 \\
1 \\
5 \\
6 \\
2 \\
0.5 \\
0.5 \\
0.5 \\
2\end{array}$ & $\begin{array}{l}6 \mathrm{~T} \\
4.2 \mathrm{~T}+8.3 \mathrm{~F} \\
6(\mathrm{~T}-\mathrm{A})+7.5 \mathrm{~F} \\
5 \mathrm{~T} \\
5 \mathrm{~T} \\
3.5 \mathrm{~T} \\
4 \mathrm{~T} \\
3.5 \mathrm{~T}\end{array}$ \\
\hline 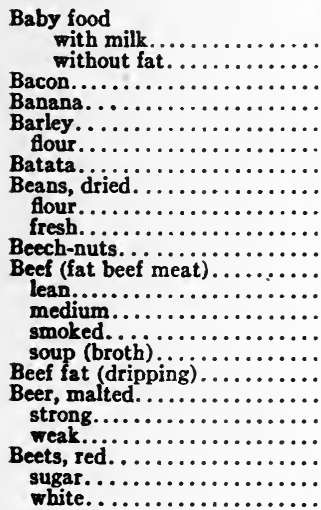 & $\begin{array}{l}5.5 \\
5 \\
10 \\
1 \\
4.5 \\
5 \\
1.25 \\
4 \\
5 \\
0.5 \\
6.7 \\
4 \\
1.5 \\
2.5 \\
5 \\
0.1 \\
13.3 \\
0.67 \\
0.33 \\
0.2 \\
0.4 \\
1 \\
0.4\end{array}$ & $\begin{array}{r}18 \\
20 \\
10 \\
100 \\
22 \\
20 \\
80 \\
25 \\
20 \\
200 \\
15 \\
25 \\
67 \\
40 \\
20 \\
1000 \\
7.5 \\
150 \\
300 \\
500 \\
250 \\
100 \\
250\end{array}$ & $\begin{array}{l}1 \\
1 \\
0.5 \\
0.5 \\
1 \\
1 \\
0.5 \\
2 \\
2 \\
2 \\
1 \\
3 \\
8 \\
4 \\
3 \\
3 \\
0 \\
0 \\
0 \\
0 \\
1 \\
0.5 \\
1\end{array}$ & $\begin{array}{l}5.5 \mathrm{~T}+8 \mathrm{~F} \\
5.5 \mathrm{~T} \\
6(\mathrm{~T}-\mathrm{A}+7.5 \mathrm{~F}) \\
5.2 \mathrm{~T} \\
5.5 \mathrm{~T} \\
5 \mathrm{~T} \\
4.5 \mathrm{~T} \\
5.5 \mathrm{~T} \\
4.5 \mathrm{~T} \\
4.2 \mathrm{~T}+8.3 \mathrm{~F} \\
15.4 \mathrm{~T}-2.22 \\
5.7 \mathrm{~F}+7.8 \mathrm{~F} \\
6(\mathrm{~T}-\mathrm{A})+7.5 \mathrm{~F} \\
13.5 \mathrm{~T} \\
5.8 \mathrm{~T} \\
5.8 \mathrm{~T} \\
5.8 \mathrm{~T} \\
4.5 \mathrm{~T} \\
4.5 \mathrm{~T}\end{array}$ \\
\hline
\end{tabular}




\begin{tabular}{|c|c|c|c|c|}
\hline 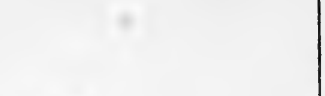 & $\begin{array}{l}\text { Nem } \\
\text { in 1 } \\
\text { gram. }\end{array}$ & $\begin{array}{c}\text { Hekto- } \\
\text { nem } \\
\text { weight, } \\
\text { grams. }\end{array}$ & $\begin{array}{c}\text { Protein } \\
\text { value. }\end{array}$ & Formulas. \\
\hline 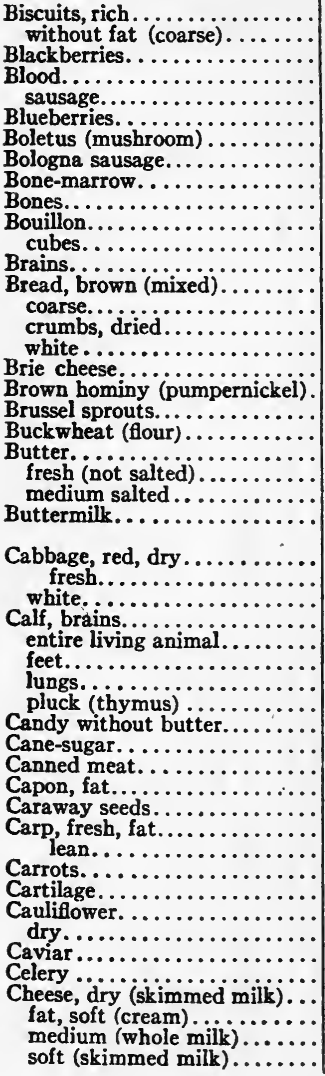 & 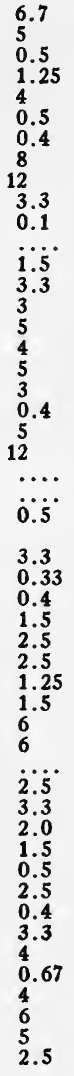 & 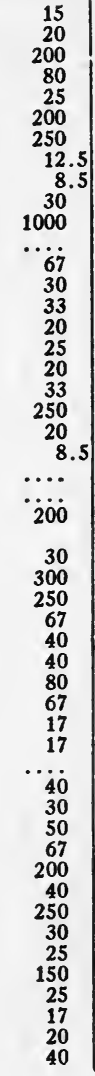 & 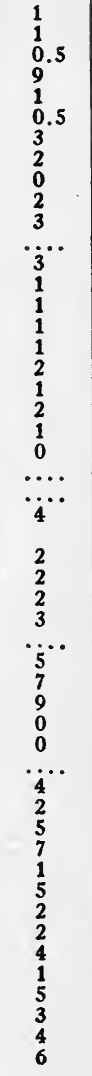 & $\begin{array}{l}5.5 \mathrm{~T}+8 \mathrm{~F} \\
5.5 \mathrm{~T} \\
3.5 \mathrm{~T} \\
5.9 \mathrm{~T} \\
6(\mathrm{~T}-\mathrm{A})+7.5 \mathrm{~F} \\
2.5 \mathrm{~T} \\
4.5 \mathrm{~T} \\
6(\mathrm{~T}-\mathrm{A})+7.5 \mathrm{~F} \\
6(\mathrm{~T}-\mathrm{A})+7.5 \mathrm{~F} \\
6(\mathrm{~T}-\mathrm{A})+7.5 \mathrm{~F} \\
6(\mathrm{~T}-\mathrm{A})+7.5 \mathrm{~F} \\
5.5 \mathrm{~T}+8 \mathrm{~F} \\
5.5 \mathrm{~T} \\
5.2 \mathrm{~T} \\
5.5 \mathrm{~T} \\
5.8 \mathrm{~T} \\
6(\mathrm{~T}-\mathrm{A})+7.5 \mathrm{~F} \\
5 \mathrm{~T} \\
4 \mathrm{~T} \\
5.5 \mathrm{~T} \\
13.4(\mathrm{~T}-\mathrm{A}) \\
13.5 \mathrm{~T}-0.1 \\
13.5 \mathrm{~T}-0.3 \\
13.5 \mathrm{~F}+0.5 \\
13.5 \mathrm{~T}-0.72 \\
4 \mathrm{~T} \\
4 \mathrm{~T} \\
5.5 \mathrm{~T}+8 \mathrm{~F} \\
6(\mathrm{~T}-\mathrm{A})+7.5 \mathrm{~F} \\
5.9 \mathrm{~T} \\
5.9 \mathrm{~T} \\
6(\mathrm{~T}-\mathrm{A})+7.5 \mathrm{~F} \\
15.4 \mathrm{~T}-2.22 \\
13.5 \mathrm{~T}-1.57 \\
13.5 \mathrm{~T}-1.57 \\
4.5 \mathrm{~T} \\
6(\mathrm{~T}-\mathrm{A})+7.5 \mathrm{~F} \\
4 \mathrm{~T} \\
6(\mathrm{~T}-\mathrm{A})+7.5 \mathrm{~F} \\
4.5 \mathrm{~T} \\
6(\mathrm{~T}-\mathrm{A})+7.5 \mathrm{~F} \\
6 \mathrm{~T}+7.5 \mathrm{~F}-0.3 \\
6(\mathrm{~T}-\mathrm{A})+7.5 \mathrm{~F}\end{array}$ \\
\hline
\end{tabular}


NEM VALUE OF PRINCIPAL FOOD-STUFFS 81

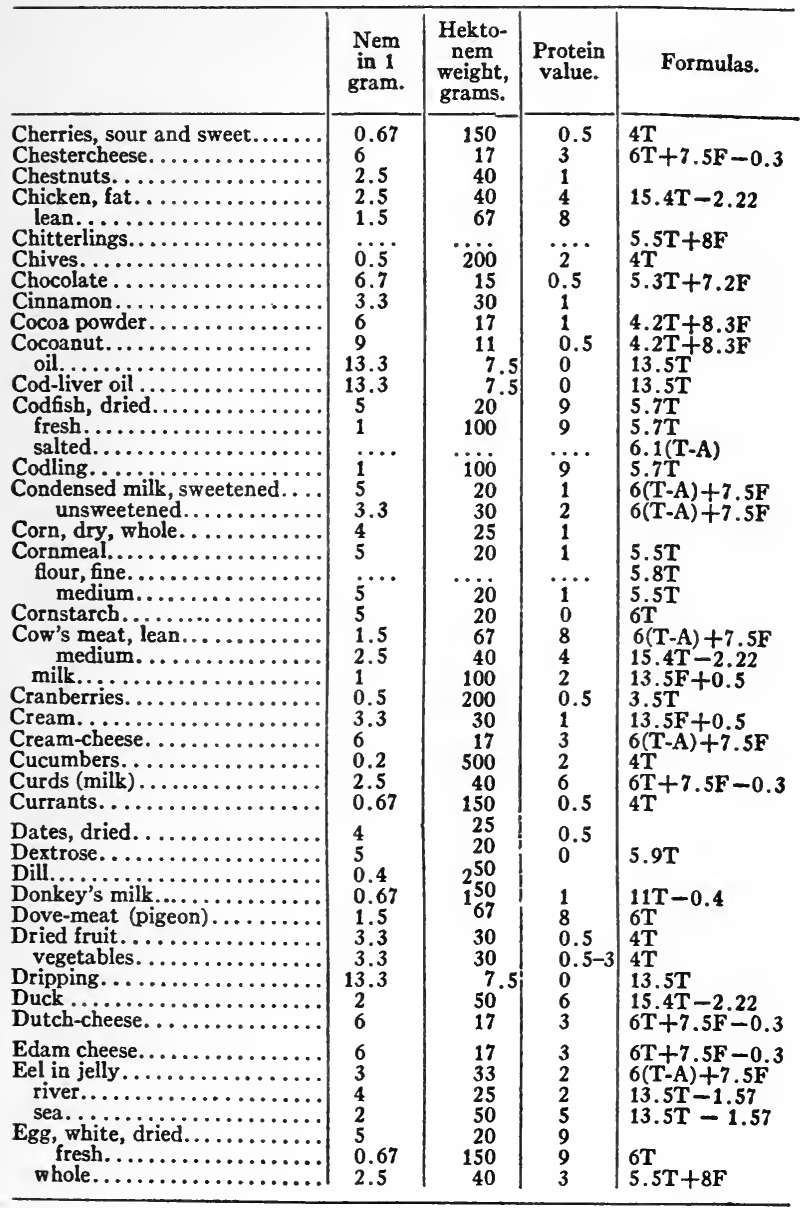




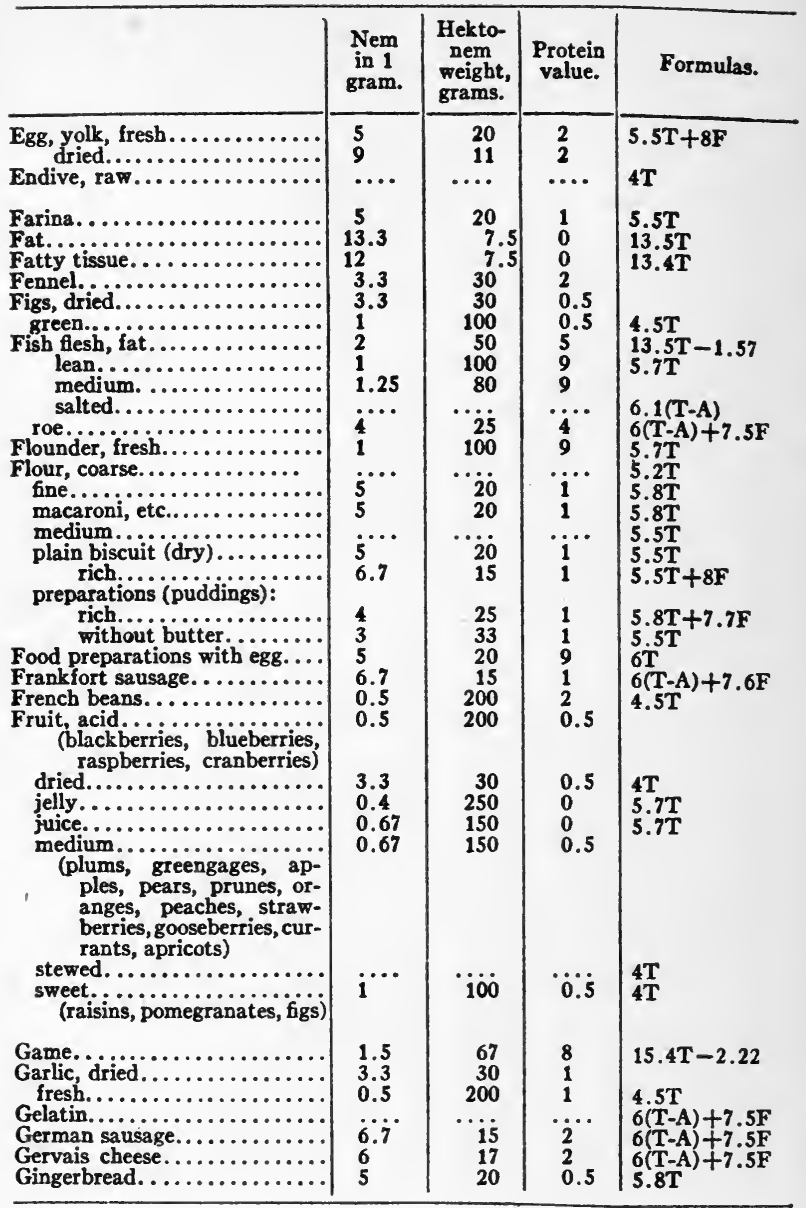




\begin{tabular}{|c|c|c|c|c|}
\hline & $\begin{array}{l}\text { Nem } \\
\text { in 1 } \\
\text { gram. }\end{array}$ & $\begin{array}{l}\text { Hekto- } \\
\text { nem } \\
\text { weight, } \\
\text { grams. }\end{array}$ & $\begin{array}{c}\text { Protein } \\
\text { value. }\end{array}$ & Formulas. \\
\hline 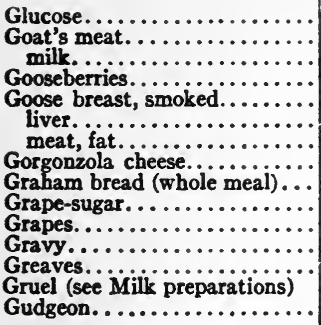 & $\begin{array}{l}5 \\
2 \\
1 \\
0.67 \\
5 \\
3 \\
6 \\
3 \\
5 \\
1 \\
1 \\
6.7 \\
1.25\end{array}$ & $\begin{array}{r}20 \\
50 \\
100 \\
150 \\
20 \\
\cdots 20 \\
20 \\
17 \\
33 \\
20 \\
100 \\
100 \\
15 \\
80\end{array}$ & $\begin{array}{l}0 \\
6 \\
2 \\
0.5 \\
3 \\
\dddot{2} \\
3 \\
1 \\
0 \\
0.5 \\
3 \\
4 \\
8\end{array}$ & $\begin{array}{l}5.9 \mathrm{~T} \\
15.4 \mathrm{~T}-2.22 \\
13.5 \mathrm{~F}+0.5 \\
4 \mathrm{~T} \\
6(\mathrm{~T}-\mathrm{A})+7.5 \mathrm{~F} \\
5.5 \mathrm{~T}+8 \mathrm{~F}-.22 \\
15.4 \mathrm{~T}-2.22 \\
6 \mathrm{~T}+7.5 \mathrm{~F}-0.3 \\
5.2 \mathrm{~T} \\
5 \mathrm{~T} \\
6(\mathrm{~T}-\mathrm{A})+7.5 \mathrm{~F} \\
6(\mathrm{~T}-\mathrm{A})+7.5 \mathrm{~F} \\
5.7 \mathrm{~T}\end{array}$ \\
\hline 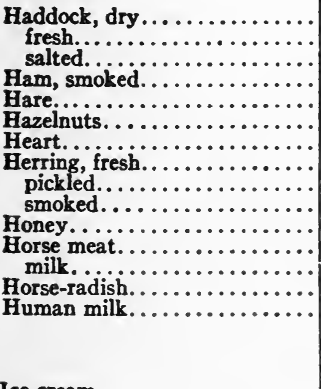 & $\begin{array}{l}5 \\
1 \\
5 \\
1.5 \\
9 \\
2.5 \\
2 \\
3.3 \\
2.5 \\
5 \\
1.5 \\
0.67 \\
1 \\
1\end{array}$ & $\begin{array}{r}20 \\
100 \\
\cdots 20 \\
67 \\
11 \\
40 \\
50 \\
30 \\
40 \\
20 \\
67 \\
150 \\
100 \\
100\end{array}$ & \begin{tabular}{l}
9 \\
9 \\
\hdashline 3 \\
8 \\
1 \\
4 \\
5 \\
5 \\
5 \\
0 \\
8 \\
1 \\
1 \\
1
\end{tabular} & $\begin{array}{l}5.7 \mathrm{~T} \\
5.7 \mathrm{~T} \\
6.1(\mathrm{~T}-\mathrm{A}) \\
6(\mathrm{~T}-\mathrm{A})+7.5 \mathrm{~F} \\
6 \mathrm{~T} \\
4.2 \mathrm{~T}+8.3 \mathrm{~F} \\
5.7 \mathrm{~T}+7.8 \mathrm{~F} \\
13.5 \mathrm{~T}-1.57 \\
6(\mathrm{~T}-\mathrm{A})+7.5 \mathrm{~F} \\
6(\mathrm{~T}-\mathrm{A})+7.5 \mathrm{~F} \\
5.9 \mathrm{~T} \\
6 \mathrm{~T} \\
11 \mathrm{~T}-0.4 \\
13.5 \mathrm{~F}+0.5 \\
13.5 \mathrm{~T}-0.67 \\
5.8 \mathrm{~T}+7.7 \mathrm{~F}\end{array}$ \\
\hline Ice-cream............ & $\cdots$ & $\cdots$ & $\cdots$ & $6(\mathrm{~T}-\mathrm{A})+7.5 \mathrm{~F}$ \\
\hline 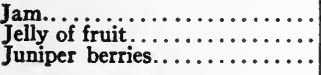 & $\begin{array}{l}3.3 \\
0.4 \\
3.3\end{array}$ & $\begin{array}{r}30 \\
250 \\
30\end{array}$ & $\begin{array}{l}0 \\
0 \\
1\end{array}$ & $\begin{array}{l}5 \mathrm{~T} \\
5.7 \mathrm{~T}\end{array}$ \\
\hline 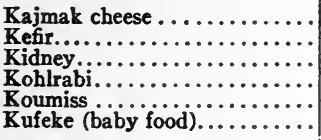 & $\begin{array}{l}6 \\
0.67 \\
1.5 \\
0.4 \\
0.67 \\
5\end{array}$ & $\begin{array}{r}17 \\
150 \\
67 \\
250 \\
150 \\
20\end{array}$ & $\begin{array}{l}2 \\
2 \\
6 \\
1 \\
2 \\
1\end{array}$ & $\begin{array}{l}6(T-A)+7.5 F \\
13.5 F+0.5 \\
13.5 T-1.57 \\
4 T \\
13.5 F+0.5 \\
5.5 T\end{array}$ \\
\hline 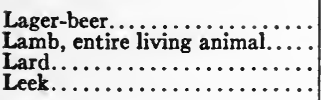 & $\begin{array}{c}0.33 \\
4 \\
13.3 \\
0.4\end{array}$ & $\begin{array}{r}300 \\
25 \\
7.5 \\
250\end{array}$ & $\begin{array}{l}0 \\
0 \\
2\end{array}$ & $\begin{array}{l}5.8 \mathrm{~T} \\
13.5 \mathrm{~T} \\
4 \mathrm{~T}\end{array}$ \\
\hline
\end{tabular}




\section{THE PIRQUET SYSTEM OF NUTRITION}

\begin{tabular}{|c|c|c|c|c|}
\hline 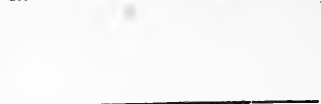 & $\begin{array}{c}\text { Nem } \\
\text { in } 1 \\
\text { gram. }\end{array}$ & $\begin{array}{l}\text { Hekto- } \\
\text { nem } \\
\text { weight, } \\
\text { grams. }\end{array}$ & $\begin{array}{c}\text { Protein } \\
\text { value. }\end{array}$ & Formulas. \\
\hline 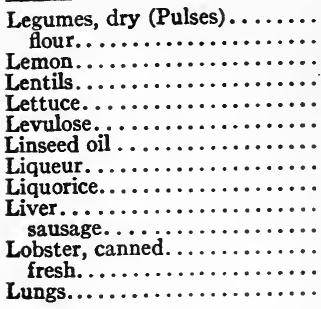 & $\begin{array}{l}4 \\
5 \\
0.67 \\
4 \\
0.2 \\
5 \\
13.3 \\
2 \\
3.3 \\
1.5 \\
6.7 \\
1.5 \\
1.5 \\
1.25\end{array}$ & $\begin{array}{r}25 \\
20 \\
150 \\
25 \\
500 \\
20 \\
7.5 \\
50 \\
30 \\
67 \\
15 \\
67 \\
100 \\
80\end{array}$ & $\begin{array}{l}2 \\
2 \\
0.5 \\
2 \\
2 \\
0 \\
0 \\
0 \\
2 \\
7 \\
1 \\
9 \\
9 \\
9\end{array}$ & $\begin{array}{l}4.5 \mathrm{~T} \\
5.5 \mathrm{~T} \\
3.5 \mathrm{~T} \\
4.5 \mathrm{~T} \\
4 \mathrm{~T} \\
5.9 \mathrm{~T} \\
13.5 \mathrm{~T} \\
5 \mathrm{~T} \\
13.5 \mathrm{~T}-1.57 \\
6(\mathrm{~T}-\mathrm{A})+7.5 \mathrm{~F} \\
6(\mathrm{~T}-\mathrm{A})+7.5 \mathrm{~F} \\
6 \mathrm{~T} \\
5.5 \mathrm{~T}+8 \mathrm{~F}\end{array}$ \\
\hline 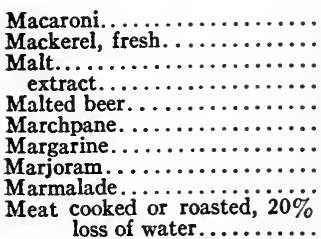 & $\begin{array}{l}5 \\
2.5 \\
5 \\
4 \\
0.67 \\
6.7 \\
12 \\
3.3 \\
3.3\end{array}$ & $\begin{array}{c}20 \\
40 \\
20 \\
25 \\
150 \\
15 \\
8.5 \\
30 \\
30\end{array}$ & $\begin{array}{l}1 \\
4 \\
0.5 \\
0 \\
0 \\
0.5 \\
0 \\
2 \\
0\end{array}$ & $\begin{array}{l}5.8 \mathrm{~T} \\
13.5 \mathrm{~T}-1.57 \\
5.8 \mathrm{~T} \\
5.8 \mathrm{~T} \\
5.8 \mathrm{~T} \\
5.3 \mathrm{~T}+7.2 \mathrm{~F} \\
13.4(\mathrm{~T}-\mathrm{A}) \\
5 \mathrm{~T} \\
5.7 \mathrm{~T}+7.8 \mathrm{~F}\end{array}$ \\
\hline 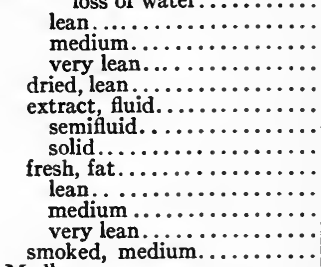 & $\begin{array}{l}2.0 \\
3.3 \\
2 \\
5 \\
1 \\
3.3 \\
5 \\
5 \\
2 \\
2.5 \\
1.5 \\
4\end{array}$ & $\begin{array}{r}30 \\
40 \\
30 \\
50 \\
20 \\
100 \\
30 \\
20 \\
20 \\
50 \\
40 \\
67 \\
25\end{array}$ & $\begin{array}{l}\dddot{6} \\
4 \\
8 \\
7 \\
8 \\
8 \\
8 \\
2 \\
6 \\
4 \\
8 \\
4\end{array}$ & $\begin{array}{l}5.7 \mathrm{~T}+7.8 \mathrm{~F} \\
5.7 \mathrm{~T}+7.8 \mathrm{~F} \\
6(\mathrm{~T}-\mathrm{A})+7.5 \mathrm{~F} \\
\\
6(\mathrm{~T}-\mathrm{A})+7.5 \mathrm{~F} \\
15.4 \mathrm{~T}-2.22 \\
15.4 \mathrm{~T}-2.22 \\
15.4 \mathrm{~T}-2.22 \\
6 \mathrm{~T}-7 \mathrm{~T}+7.8 \mathrm{~F}\end{array}$ \\
\hline 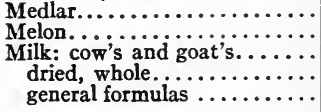 & $\begin{array}{l}\ddot{0} \ddot{4} \\
1 \\
5 \\
\cdots\end{array}$ & $\begin{array}{r}250 \\
100 \\
20 \\
\cdots\end{array}$ & $\begin{array}{l}\dddot{1} \\
2 \\
2 \\
\cdots\end{array}$ & $\begin{array}{l}4 \mathrm{~T} \\
4.5 \mathrm{~T} \\
13.5 \mathrm{~F}+0.5 \\
5.5 \mathrm{~T}+8 \mathrm{~F} \\
11 \mathrm{~T}-0.4\end{array}$ \\
\hline 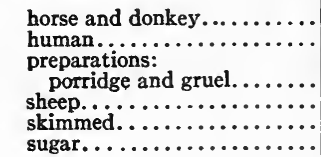 & $\begin{array}{l}0.67 \\
1 \\
1 \\
1.25 \\
0.5 \\
6\end{array}$ & $\begin{array}{r}150 \\
100 \\
100 \\
80 \\
200 \\
17\end{array}$ & $\begin{array}{l}1 \\
1 \\
1 \\
2 \\
4 \\
0\end{array}$ & $5.5 T+8 F$ \\
\hline
\end{tabular}




\begin{tabular}{|c|c|c|c|c|}
\hline & $\begin{array}{c}\text { Nem } \\
\text { in } 1 \\
\text { gram. }\end{array}$ & $\begin{array}{c}\text { Hekto- } \\
\text { nem } \\
\text { weight, } \\
\text { grams. }\end{array}$ & $\begin{array}{c}\text { Protein } \\
\text { value. }\end{array}$ & Formulas. \\
\hline 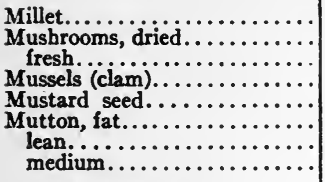 & $\begin{array}{l}4.5 \\
3.3 \\
0.4 \\
1 \\
5 \\
5 \\
2 \\
2.5\end{array}$ & $\begin{array}{r}22 \\
30 \\
250 \\
100 \\
20 \\
20 \\
50 \\
40\end{array}$ & $\begin{array}{l}1 \\
3 \\
3 \\
6 \\
2 \\
2 \\
6 \\
4\end{array}$ & $\begin{array}{l}5.2 \\
4 \mathrm{~T} \\
15.4 \mathrm{~T}-2.22 \\
5.7 \mathrm{~T}+7.8 \mathrm{~F}\end{array}$ \\
\hline 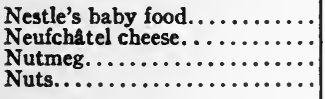 & $\begin{array}{l}5.5 \\
6 \\
3.3 \\
9\end{array}$ & $\begin{array}{l}18 \\
17 \\
30 \\
11\end{array}$ & $\begin{array}{l}1 \\
2 \\
1\end{array}$ & $\begin{array}{l}6 \mathrm{~T} \\
6(\mathrm{~T}-\mathrm{A})+7.5 \mathrm{~F} \\
4.2 \mathrm{~T}+8.3 \mathrm{~F}\end{array}$ \\
\hline 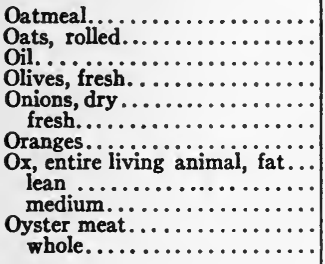 & $\begin{array}{l}5 \\
4.5 \\
13.3 \\
6 \\
3.3 \\
0.5 \\
0.67 \\
4 \\
2.5 \\
3 \\
1 \\
0.1\end{array}$ & \begin{tabular}{r|}
20 \\
22 \\
7.5 \\
17 \\
30 \\
200 \\
150 \\
25 \\
40 \\
33 \\
100 \\
1000
\end{tabular} & $\begin{array}{l}1 \\
1 \\
0 \\
1 \\
1 \\
1 \\
0.5 \\
2 \\
3 \\
5 \\
5\end{array}$ & $\begin{array}{l}5.5 \mathrm{~T} \\
5.5 \mathrm{~T} \\
13.5 \mathrm{~T} \\
4.5 \mathrm{~T} \\
4.5 \mathrm{~T}\end{array}$ \\
\hline 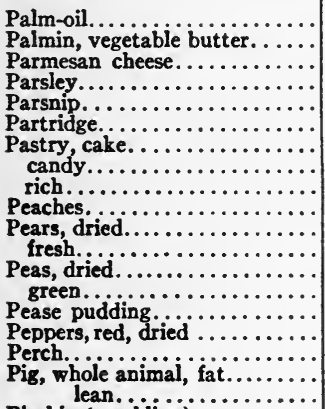 & $\begin{array}{l}13.3 \\
12 \\
5 \\
0.4 \\
1.3 \\
1.5 \\
5 \\
6 \\
6.7 \\
0.67 \\
3.3 \\
0.67 \\
4 \\
1 \\
6.7 \\
3.3 \\
1.25 \\
5 \\
3\end{array}$ & $\begin{array}{r}7.5 \\
8.5 \\
20 \\
250 \\
7.5 \\
67 \\
20 \\
17 \\
15 \\
150 \\
30 \\
150 \\
25 \\
100 \\
15 \\
30 \\
80 \\
20 \\
33\end{array}$ & $\begin{array}{l}0 \\
0 \\
4 \\
2 \\
\cdots \\
8 \\
0.5 \\
0 \\
0 \\
0.5 \\
0.5 \\
0.5 \\
2 \\
2 \\
1 \\
2 \\
8 \\
1 \\
2\end{array}$ & $\begin{array}{l}13.5 \mathrm{~T} \\
13.4 \mathrm{~T} \\
6 \mathrm{~T}+7.5 \mathrm{~F}-0.3 \\
4.5 \mathrm{~T} \\
6 \mathrm{~T} \\
5.8 \mathrm{~T} \\
5.9 \mathrm{~T} \\
5.8 \mathrm{~T}+7.7 \mathrm{~F} \\
3.5 \mathrm{~T} \\
4.5 \mathrm{~T} \\
4.5 \mathrm{~T} \\
4.5 \mathrm{~T} \\
4.5 \mathrm{~T} \\
\\
13.5 \mathrm{~T}-1.57\end{array}$ \\
\hline 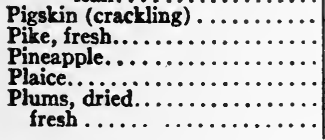 & $\begin{array}{l}12 \\
0.67 \\
1.25 \\
3.3 \\
0.67\end{array}$ & $\begin{array}{r}8.5 \\
150 \\
80 \\
30 \\
150\end{array}$ & $\begin{array}{l}0 \\
\ddot{0} .5 \\
8 \\
0.5 \\
0.5\end{array}$ & $\begin{array}{l}13.3 \mathrm{~T} \\
13.5 \mathrm{~T}-1.57 \\
5 \mathrm{~T} \\
5.7 \mathrm{~T} \\
3.5 \mathrm{~T}\end{array}$ \\
\hline
\end{tabular}




\begin{tabular}{|c|c|c|c|c|}
\hline $\mathrm{H}^{-1}$ & $\begin{array}{c}\text { Nem } \\
\text { in 1 } \\
\text { gram. }\end{array}$ & $\begin{array}{c}\text { Hekto- } \\
\text { nem } \\
\text { weight, } \\
\text { grams. }\end{array}$ & $\begin{array}{l}\text { Protein } \\
\text { value. }\end{array}$ & Formulas. \\
\hline 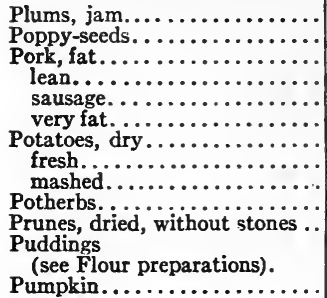 & $\begin{array}{l}3.3 \\
6.7 \\
5 \\
2 \\
6.7 \\
6 \\
4.5 \\
1.25 \\
4.5 \\
0.25 \\
3.3\end{array}$ & $\begin{array}{r}30 \\
15 \\
20 \\
50 \\
15 \\
17 \\
22 \\
80 \\
22 \\
400 \\
30\end{array}$ & $\begin{array}{l}0 \\
1 \\
2 \\
6 \\
2 \\
1 \\
0.5 \\
0.5 \\
0.5 \\
2 \\
0.5\end{array}$ & $\begin{array}{l}5 \mathrm{~T} \\
4.2 \mathrm{~T}+8.3 \mathrm{~F} \\
15.4 \mathrm{~T}-2.22 \\
6(\mathrm{~T}-\mathrm{A})+7.5 \mathrm{~F} \\
5.7 \mathrm{~T}+7.8 \mathrm{~F} \\
5 \mathrm{~T} \\
5 \mathrm{~T} \\
5 \mathrm{~T}\end{array}$ \\
\hline Quince-cheese.............. & $\ldots$. & $\cdots$ & $\ldots$ & $5.7 \mathrm{~T}$ \\
\hline 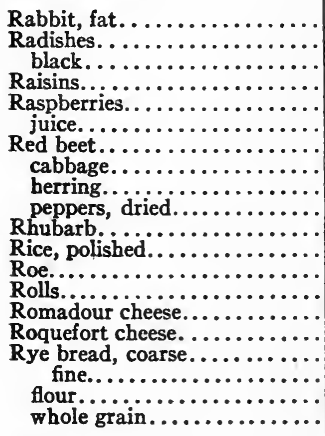 & $\begin{array}{l}2.5 \\
0.25 \\
0.5 \\
4 \\
0.5 \\
0.67 \\
0.4 \\
0.33 \\
2.5 \\
3.3 \\
0.2 \\
5 \\
4 \\
4 \\
5 \\
6 \\
3 \\
3.3 \\
5 \\
4\end{array}$ & $\begin{array}{r}40 \\
400 \\
200 \\
25 \\
200 \\
150 \\
250 \\
300 \\
40 \\
30 \\
500 \\
20 \\
25 \\
25 \\
20 \\
17 \\
33 \\
30 \\
20 \\
25\end{array}$ & $\begin{array}{l}4 \\
2 \\
1 \\
0.5 \\
0.5 \\
0 \\
1 \\
2 \\
6 \\
2 \\
1 \\
0.5 \\
4 \\
1 \\
3 \\
3 \\
1 \\
1 \\
1 \\
1\end{array}$ & $\begin{array}{l}15.4 \mathrm{~T}-2.22 \\
4 \mathrm{~T} \\
4 \mathrm{~T} \\
5 \mathrm{~T} \\
3 \mathrm{~T} \\
5.8 \mathrm{~T} \\
4.5 \mathrm{~T} \\
4 \mathrm{~T} \\
6(\mathrm{~T}-\mathrm{A})+7.5 \mathrm{~F} \\
4 \mathrm{~T} \\
5.5 \mathrm{~T} \\
6(\mathrm{~T}-\mathrm{A})+7.5 \mathrm{~F} \\
5.8 \mathrm{~T} \\
6 \mathrm{~T}+7.5 \mathrm{~F}-0.3 \\
6 \mathrm{~T}+7.5 \mathrm{~F}-0.3 \\
5.2 \mathrm{~T} \\
5.5 \mathrm{~T} \\
5.5 \mathrm{~T}\end{array}$ \\
\hline 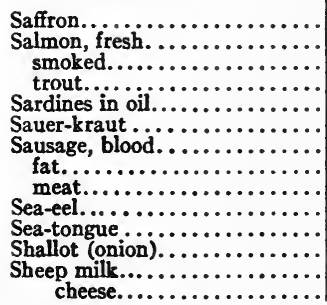 & $\begin{array}{l}3.3 \\
3.3 \\
i .25 \\
3 \\
0.33 \\
4 \\
6.7 \\
6.7 \\
2 \\
1 \\
0.5 \\
1.25 \\
\cdots\end{array}$ & $\begin{array}{r}30 \\
30 \\
380 \\
33 \\
300 \\
25 \\
15 \\
15 \\
50 \\
100 \\
200 \\
80 \\
\ldots\end{array}$ & $\begin{array}{l}1 \\
4 \\
\dddot{9} \\
5 \\
2 \\
1 \\
1 \\
2 \\
5 \\
9 \\
1 \\
2 \\
\cdots\end{array}$ & $\begin{array}{l}13.5 \mathrm{~T}-1.57 \\
6(\mathrm{~T}-\mathrm{A})+7.5 \mathrm{~F} \\
5.7 \mathrm{~T} \\
6(\mathrm{~T}-\mathrm{A})+7.5 \mathrm{~F} \\
3 \mathrm{~T} \\
6(\mathrm{~T}-\mathrm{A})+7.5 \mathrm{~F} \\
13.5 \mathrm{~T}-1.57 \\
5.7 \mathrm{~T} \\
4.5 \mathrm{~T} \\
11 \mathrm{~T}-0.4 \\
6(\mathrm{~T}-\mathrm{A})+7.5 \mathrm{~F}\end{array}$ \\
\hline
\end{tabular}


NEM VALUE OF PRINCIPAL FOOD-STUFFS 87

\begin{tabular}{|c|c|c|c|c|}
\hline 1 & $\begin{array}{l}\text { Nem } \\
\text { in } 1 \\
\text { gram. }\end{array}$ & $\begin{array}{l}\text { Hekto- } \\
\text { nem } \\
\text { weight, } \\
\text { grams. }\end{array}$ & $\begin{array}{c}\text { Protein } \\
\text { value. }\end{array}$ & Formulas. \\
\hline 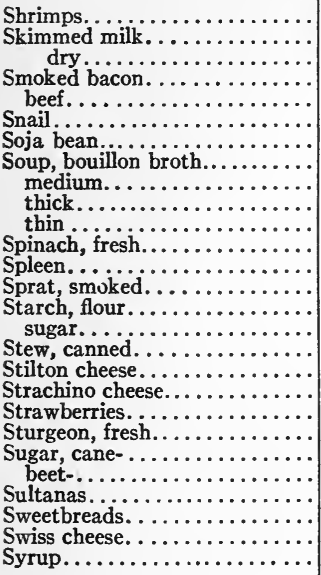 & $\begin{array}{l}1 \\
0.5 \\
5 \\
10 \\
4 \\
1 \\
4 \\
0.1 \\
0.67 \\
1 \\
0.5 \\
0.4 \\
1.5 \\
3.3 \\
5 \\
5 \\
\dddot{6} .7 \\
6 \\
0.67 \\
1.25 \\
6 \\
6 \\
4 \\
1.5 \\
6 \\
5\end{array}$ & $\begin{array}{r}100 \\
200 \\
20 \\
10 \\
25 \\
100 \\
25 \\
1000 \\
150 \\
100 \\
200 \\
250 \\
67 \\
30 \\
20 \\
20 \\
\cdots \\
15 \\
17 \\
150 \\
80 \\
17 \\
17 \\
25 \\
67 \\
17 \\
20\end{array}$ & $\begin{array}{l}9 \\
4 \\
4 \\
0.5 \\
4 \\
7 \\
3 \\
3 \\
1 \\
1 \\
1 \\
3 \\
6 \\
4 \\
0 \\
0 \\
\dddot{2} \\
2 \\
0.5 \\
8 \\
0 \\
0 \\
0.5 \\
9 \\
3 \\
0\end{array}$ & $\begin{array}{l}6 \mathrm{~T} \\
13.5 \mathrm{~F}+0.5 \\
5.5 \mathrm{~T}-8 \mathrm{~F} \\
6(\mathrm{~T}-\mathrm{A})+7.5 \mathrm{~F} \\
6(\mathrm{~T}-\mathrm{A})+7.5 \mathrm{~F} \\
4.5 \mathrm{~T} \\
6(\mathrm{~T}-\mathrm{A})+7.5 \mathrm{~F} \\
6(\mathrm{~T}-\mathrm{A})+7.5 \mathrm{~F} \\
6(\mathrm{~T}-\mathrm{A})+7.5 \mathrm{~F} \\
6(\mathrm{~T}-\mathrm{A})+7.5 \mathrm{~F} \\
4 \mathrm{~T} \\
13.5 \mathrm{~T}-1.57 \\
6(\mathrm{~T}-\mathrm{A})+7.5 \mathrm{~F} \\
6 \mathrm{~T} \\
5.9 \mathrm{~T} \\
6(\mathrm{~T}-\mathrm{A})+7.5 \mathrm{~F} \\
6 \mathrm{~T}+7.5 \mathrm{~F}-0.1 \\
6 \mathrm{~T}+7.5 \mathrm{~F}-0.1 \\
5 \mathrm{~T} \\
5.7 \mathrm{~T} \\
5.9 \mathrm{~T} \\
5.9 \mathrm{~T} \\
5 \mathrm{~T} \\
5.5 \mathrm{~T}+8 \mathrm{~F} \\
6 \mathrm{~T}+7.5 \mathrm{~F}-0.3 \\
5.9 \mathrm{~T}\end{array}$ \\
\hline 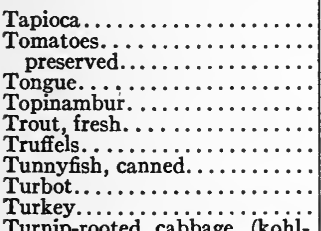 & $\begin{array}{l}5 \\
0.25 \\
1 \\
3.3 \\
1 \\
1.5 \\
4 \\
1.5 \\
2.5\end{array}$ & $\begin{array}{r}20 \\
400 \\
100 \\
30 \\
100 \\
67 \\
25 \\
25 \\
67 \\
40\end{array}$ & \begin{tabular}{l}
0 \\
2 \\
2 \\
3 \\
0.5 \\
9 \\
\hdashline 9 \\
7 \\
4
\end{tabular} & $\begin{array}{l}6 \mathrm{~T} \\
4 \mathrm{~T} \\
4 \mathrm{~T} \\
13.5 \mathrm{~T}-1.57 \\
5 \mathrm{~T} . \\
13.5 \mathrm{~T}-1.57 \\
3 \mathrm{~T} \\
6(\mathrm{~T}-\mathrm{A})+7.5 \mathrm{~F} \\
13.5 \mathrm{~T}-1.57 \\
15.4 \mathrm{~T}-2.22\end{array}$ \\
\hline 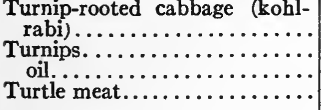 & $\begin{array}{c}0.4 \\
0.4 \\
13.3 \\
1\end{array}$ & $\begin{array}{l}250 \\
250 \\
7.5 \\
100\end{array}$ & $\begin{array}{l}1 \\
1 \\
0 \\
6\end{array}$ & $\begin{array}{l}4 \mathrm{~T} \\
4.5 \mathrm{~T} \\
13.5 \mathrm{~T} \\
6 \mathrm{~T}\end{array}$ \\
\hline Udder.................... & 2.5 & 40 & 2 & $6(\mathrm{~T}-\mathrm{A})+7.5 \mathrm{~F}$ \\
\hline 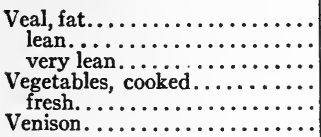 & $\begin{array}{l}2.5 \\
2.0 \\
1.5 \\
\dddot{0} .4 \\
1.5\end{array}$ & $\begin{array}{r}40 \\
50 \\
67 \\
250 \\
250\end{array}$ & $\begin{array}{l}4 \\
6 \\
8 \\
\dddot{2} \\
8\end{array}$ & $\begin{array}{l}15.4 \mathrm{~T}-2.22 \\
15.4 \mathrm{~T}-2.22 \\
15.4 \mathrm{~T}-2.22 \\
4 \mathrm{~T}+9.5 \mathrm{~F} \\
4 \mathrm{~T} \\
6 \mathrm{~T}\end{array}$ \\
\hline
\end{tabular}




\section{THE PIRQUET SYSTEM OF NUTRITION}

\begin{tabular}{|c|c|c|c|c|}
\hline 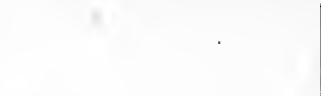 & $\begin{array}{c}\text { Nem } \\
\text { in 1 } \\
\text { gram. }\end{array}$ & $\begin{array}{c}\text { Hekto- } \\
\text { nem } \\
\text { weight, } \\
\text { grams. }\end{array}$ & $\begin{array}{l}\text { Protein } \\
\text { value. }\end{array}$ & Formulas. \\
\hline 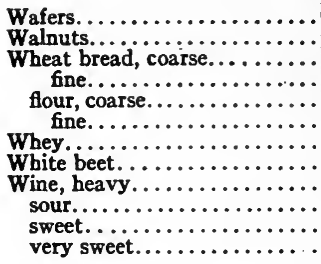 & $\begin{array}{l}5 \\
9 \\
3.3 \\
4 \\
5 \\
5 \\
0.4 \\
0.4 \\
0.2 \\
0.1 \\
0.4 \\
1.0\end{array}$ & $\begin{array}{r}20 \\
11 \\
30 \\
25 \\
20 \\
20 \\
250 \\
250 \\
500 \\
1000 \\
250 \\
100\end{array}$ & $\begin{array}{l}1 \\
0.5 \\
1 \\
1 \\
1 \\
1 \\
1 \\
1 \\
0 \\
0 \\
0 \\
0\end{array}$ & $\begin{array}{l}5.8 \mathrm{~T} \\
4.2 \mathrm{~T}+8.3 \mathrm{~F} \\
5.5 \mathrm{~T} \\
5.8 \mathrm{~T} \\
5.5 \mathrm{~T} \\
5.8 \mathrm{~T} \\
5.8 \mathrm{~T} \\
4.5 \mathrm{~T} \\
5 \mathrm{~T}\end{array}$ \\
\hline 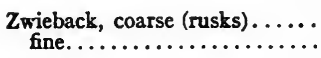 & $\begin{array}{l}5 \\
\cdots\end{array}$ & $\begin{array}{r}20 \\
\cdots\end{array}$ & 1 & $5.5 \mathrm{~T}$ \\
\hline
\end{tabular}




\section{PELIDISI TABLE}

\section{HOW TO FIND THE PELIDISI BY MEANS OF THE TABLE}

Read from left to right along the topmost row of figures until you reach the predetermined figure giving the sitting beight; then read down the corresponding vertical column until you arrive at the figure which is the weight of the individual; then follow the line next below to the right or left, and you will arrive at the Pelidisi figure. If the figure giving the weight of the individual lies at a point between two figures given on the chart, then follow the line between these two figures as directed above.

Example: A child with a sitting height of 40 centimeters and a net weight of $5.40 \mathrm{~kg}$.

Look for figure 40 along the topmost row of figures, then read down the corresponding vertical column until you come to the figure 5.40. The line below this figure leads to (right or left) the Pelidisi figure 95 . If the child has a sitting height of 40 centimeters and a weight of $5.20 \mathrm{~kg}$., it is found that this latter figure lies between 5.07 and $\mathbf{5 . 2 3}$. In this case follow the horizontal line between these two figures to the Pelidisi figure 93.

All particulars about this table are to be found in Pirquet, System der Ernährung, Berlin, Julius Springer, 1919, 2d part, pp. 284-312. 


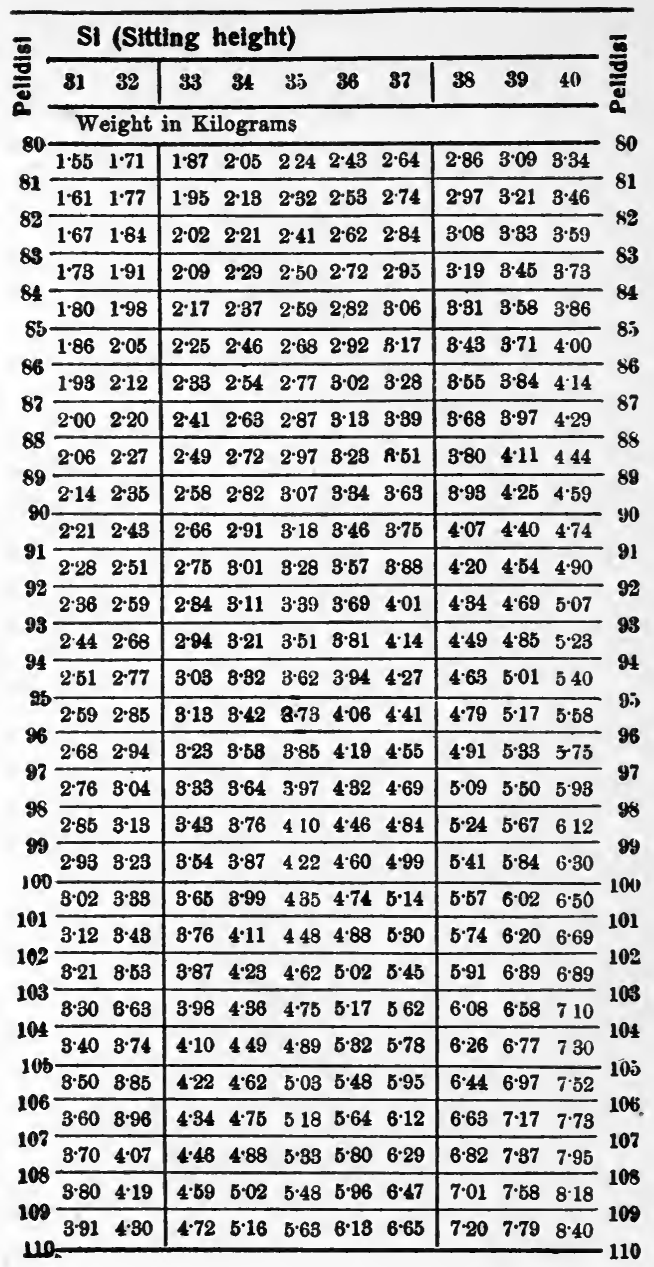




\begin{tabular}{|c|c|c|c|c|c|c|c|c|c|c|}
\hline \multirow{3}{*}{ 흠 } & \multicolumn{9}{|c|}{ Si (Sitting height) } & \multirow[b]{2}{*}{ : } \\
\hline & 41 & & & & & & & 8 & 50 & \\
\hline & & & & & & \multicolumn{4}{|c|}{ Weight in Kilograms } & \\
\hline 81 . & 3 & 6 & 5 & 444 & $4 \cdot 75$ & 5.08 & 42 & $5 \cdot 77 \quad 6 \cdot 14$ & 6.52 & \\
\hline 81 & $3 \cdot 73$ & 4.01 & 30 & & & $5 \cdot 27$ & $5 \cdot 62$ & $5.99 \quad 6.37$ & 6.77 & \\
\hline 9 & 3.87 & s & 6 & 7 & $5 \cdot 12$ & $5 \cdot 47$ & $5 \cdot 83$ & $6.21 \quad 6.61$ & $7 \cdot$ & \\
\hline \multirow{2}{*}{$\begin{array}{l}83 \\
84\end{array}$} & 4.0 & 31 & 33 & 6 & $5 \cdot 31$ & $5 \cdot 67$ & 6.05 & $6.44 \quad 6.85$ & $7 \cdot 28$ & \\
\hline & $4 \cdot 16$ & $4 \cdot 47$ & 30 & 14 & $5 \cdot 50$ & $5 \cdot 87$ & $6 \cdot 26$ & $6.67 \quad 7 \cdot 10$ & $7 \cdot 54$ & \\
\hline 85 & $4 \div 31$ & 63 & 7 & 32 & $5 \cdot 70$ & 6.08 & 6.49 & $6.91 \quad 7.35$ & $7 \cdot 81$ & \\
\hline \multirow{2}{*}{87} & 4.46 & $4: 80$ & 15 & $5 \cdot 51$ & $5 \cdot 90$ & $6 \cdot 30$ & 6.72 & $7 \cdot 16 \quad 7 \cdot 61$ & 8.09 & \\
\hline & $4 \cdot 62$ & 00 & $5 \cdot 33$ & $5 \cdot 71$ & $6 \cdot 10$ & 6.52 & 6.96 & $7 \cdot 41 \quad 7 \cdot 88$ & $8 \cdot 37$ & \\
\hline \multirow{2}{*}{89} & $4 \cdot 78$ & $5 \cdot 14$ & 51 & $5 \cdot 90$ & $6 \cdot 32$ & $6 \cdot 75$ & $7 \cdot 20$ & $7 \cdot 67 \quad 8 \cdot 15$ & 8.66 & \\
\hline & $4 \cdot 94$ & $5 \cdot 31$ & $5 \cdot 70$ & $6 \cdot 11$ & 6.53 & 6.98 & $7 \cdot 44$ & $7.93 \quad 8.44$ & $8 \cdot 96$ & \\
\hline \multirow{2}{*}{91} & $5 \cdot 11$ & 49 & 89 & $6 \cdot 31$ & $6 \cdot 75$ & $7 \cdot 21$ & $7 \cdot 70$ & \begin{tabular}{|ll}
8.20 & 8.72 \\
\end{tabular} & $9 \cdot 27$ & \\
\hline & $5 \cdot 28$ & $5 \cdot 68$ & 6.09 & 6.53 & 6.98 & $7 \cdot 46$ & $7 \cdot 95$ & $8.47 \quad 9.01$ & 9.58 & \\
\hline \multirow{2}{*}{93} & 5.46 & 86 & 9 & 74 & $7 \cdot 21$ & $7 \cdot 70$ & $8 \cdot 22$ & $8.75 \quad 9.31$ & 9 & \\
\hline & $5 \cdot 63$ & 6.06 & 6.50 & 6.96 & 745 & $7 \cdot 96$ & 8.49 & $9.04 \quad 9.62$ & $10 \cdot 2$ & \\
\hline 94 & 5.8 & 25 & 70 & $7 \cdot 19$ & $7 \cdot 69$ & $8 \cdot 21$ & $8 \cdot 76$ & $9.83 \quad 9.93$ & 1 & \\
\hline \multirow{2}{*}{$\begin{array}{l}95 \\
96\end{array}$} & 6.00 & 6.45 & 6.93 & $7 \cdot 42$ & 7.94 & $8 \cdot 48$ & 9.04 & $\begin{array}{|ll|}9 \cdot 63 & 10^{\circ} 2 \\
\end{array}$ & $10 \cdot 9$ & \\
\hline & $6 \cdot 19$ & 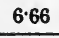 & 14 & $7 \cdot 66$ & $8 \cdot 19$ & 8.75 & $9 \cdot 38$ & $9.94 \quad 10.6$ & $11 \cdot 2$ & \\
\hline 97 & 6.39 & 6.87 & $7 \cdot 37$ & $7 \cdot 90$ & 8.45 & $9 \cdot 02$ & $9 \cdot 62$ & $10.3 \quad 10.9$ & 11.6 & \\
\hline \multirow{2}{*}{$\begin{array}{l}98 \\
99\end{array}$} & 6.59 & $7 \cdot 08$ & 60 & $8 \cdot 14$ & 8.71 & 9.30 & $9 \cdot 92$ & $10^{\circ} 611^{\circ} 2$ & 110 & \\
\hline & 6.79 & $7 \cdot 30$ & $7 \cdot 83$ & $8 \cdot 39$ & 8.98 & 9.59 & 10.2 & $10.9 \quad 11.6$ & $12 \cdot 3$ & \\
\hline \multirow{2}{*}{101} & $7 \cdot 00$ & $7 \cdot 52$ & 8.07 & 8.65 & $9 \cdot 25$ & $9 \cdot 88$ & 100 & $11.2 \quad 11.9$ & 12.7 & \\
\hline & $7 \cdot 21$ & $7 \cdot 75$ & $8 \cdot 31$ & 8.91 & $9 \cdot 53$ & $10 \cdot 2$ & 109 & $11.6 \quad 12.3$ & $13 \cdot 1$ & \\
\hline \multirow{2}{*}{$\begin{array}{l}102 \\
103\end{array}$} & $7 \cdot 42$ & $7 \cdot 98$ & 8.56 & $9 \cdot 17$ & $9 \cdot 81$ & 10.5 & 112 & $11.9 \quad 12.7$ & 13.6 & \\
\hline & $7 \cdot 64$ & 8.21 & 8.82 & 9.44 & 10.1 & 10.8 & $11 \cdot 5$ & $12.3 \quad 18.0$ & 13.9 & \\
\hline \multirow{2}{*}{$\begin{array}{l}104 \\
105\end{array}$} & $7 \cdot 87$ & 8.45 & 9.07 & $9 \cdot 72$ & 10.4 & 111 & $11 \cdot 8$ & $12.6 \quad 13.4$ & $14: 3$ & \\
\hline & $8 \cdot 10$ & 8.70 & $9 \cdot 34$ & 10.0 & 10.7 & $11 \cdot 4$ & $12 \cdot 2$ & $130 \quad 13.8$ & 14.7 & \\
\hline 106 & $8 \cdot 33$ & 8.95 & 9.60 & 10.3 & 11.0 & $11 \cdot 8$ & $12 \cdot 5$ & $\begin{array}{|ll|}13.4 & 14.2 \\
\end{array}$ & 15.1 & \\
\hline 107 & 8.5 & $9 \cdot 20$ & 9.88 & $10 \cdot 6$ & 11.8 & $12 \cdot 1$ & $12 \cdot 9$ & $13.7 \quad 14.6$ & $15 \cdot 5$ & \\
\hline \multirow{2}{*}{$\begin{array}{l}108 \\
109\end{array}$} & $8 \cdot 80$ & 9.46 & $10 \cdot 2$ & 10.9 & $11 \cdot 6$ & $12 \cdot 4$ & $18 \cdot 3$ & $14: 1 \quad 15 \cdot 0$ & 16.0 & \\
\hline & 9.05 & $9 \cdot 7$ & 0.4 & $11 \cdot 2$ & $12 \cdot 0$ & $12 \cdot 8$ & 13.6 & $14.5 \quad 15.4$ & 164 & \\
\hline
\end{tabular}




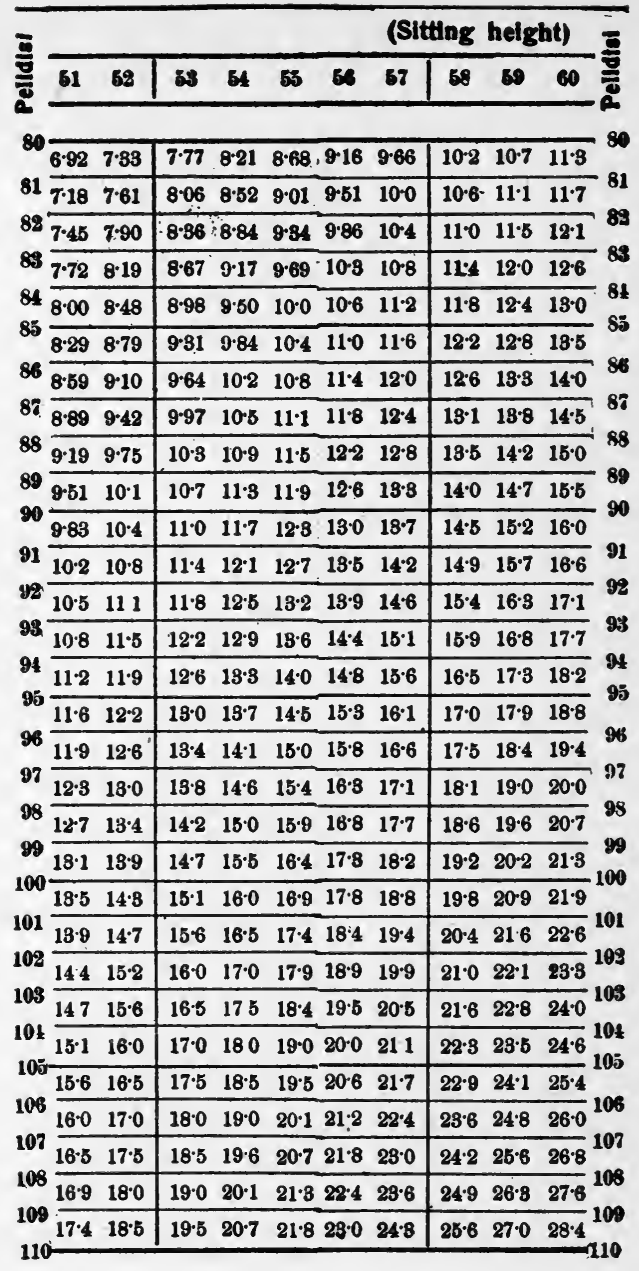




\begin{tabular}{|c|c|c|c|c|c|c|c|c|c|c|c|}
\hline \multirow{3}{*}{ 흘 } & \multicolumn{10}{|c|}{ Si (Sitting helght) } & \multirow{2}{*}{$\frac{\overline{3}}{\overline{0}}$} \\
\hline & & & & & & & & & 39 & 60 & \\
\hline & \multicolumn{10}{|c|}{ Weight in Kilograms } & \\
\hline & & 24 & $13 \cdot 0$ & 18.7 & $14 \cdot 3$ & $15 \cdot 0$ & $15 \cdot 7$ & 4 & 1 & & \multirow{2}{*}{-81} \\
\hline & & $12 \cdot 9$ & 13.5 & $314 \cdot 2$ & 14.9 & 15.6 & $16 \cdot 3$ & 70 & 17.8 & 6 & \\
\hline \multirow[b]{2}{*}{3} & $12 \cdot 7$ & 3.4 & 14.0 & $014 \cdot 7$ & $15 \cdot 4$ & $16 \cdot 1$ & 16.9 & $17 \cdot ?$ & $18 \cdot 5$ & $19 \cdot 3$ & \\
\hline & $13 \cdot 2$ & 8.9 & $14 \cdot 6$ & $6,15 \cdot 3$ & 16.0 & $16 \cdot 7$ & $17 \cdot 5$ & $8 \cdot 3$ & $19 \cdot 1$ & 20.0 & \\
\hline \multirow[b]{2}{*}{ 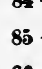 } & 13 & 1.4 & 1 & $15 \cdot 8$ & $16 \cdot 6$ & $17 \cdot 4$ & $18 \cdot 1$ & 0 & $19 \cdot 8$ & $20 \cdot 7$ & \\
\hline & $14 \cdot 2$ & $4 \cdot 9$ & $15 \cdot 6$ & $616 \cdot 4$ & $17 \cdot 2$ & $18 \cdot 0$ & $18 \cdot 8$ & $9 \cdot 6$ & 20.5 & $21 \cdot 4$ & \multirow[t]{2}{*}{86} \\
\hline \multirow{2}{*}{87} & $14 \cdot 7$ & 4 & $16^{2} 2$ & $7 \cdot 0$ & $17 \cdot 8$ & $18 \cdot 6$ & 19.5 & 9 & $21 \cdot 3$ & $2 \cdot 2$ & \\
\hline & $15 \cdot 2$ & 6.0 & $16 \cdot 7$ & $717 \cdot 6$ & $18 \cdot 4$ & $19 \cdot 3$ & $20 \cdot 1$ & $21 \cdot 1$ & $22 \cdot 0$ & $23 \cdot 0$ & \multirow[t]{2}{*}{87} \\
\hline \multirow[t]{2}{*}{89} & $15 \cdot 7$ & $8 \div 5$ & $.17 \cdot 3$ & $8 \cdot 2$ & 19.0 & 19.9 & 20.8 & 18 & 22.8 & $23 \cdot 8$ & \\
\hline & 16.3 & $17 \cdot 1$ & 17.9 & $9 \quad 18.8$ & 19.7 & 20.6 & $21 \cdot 6$ & 5 & $23 \cdot 6$ & 6 & \multirow[t]{2}{*}{90} \\
\hline \multirow{2}{*}{91} & 16.8 & $17 \cdot 7$ & 18.5 & $5 \quad 19.4$ & 20.4 & $21 \cdot 3$ & 22.3 & $23 \cdot 3$ & $24 \cdot 4$ & 25.4 & \\
\hline & $17 \cdot 4$ & $18 \cdot 3$ & $19 \cdot 2$ & 220.1 & 210 & $22 \cdot 0$ & $23 \cdot 0$ & 1 & $25 \cdot 2$ & 200 & \multirow{2}{*}{92} \\
\hline \multirow{2}{*}{93} & 18.0 & 18.9 & $19 \cdot 8$ & 8207 & $21 \cdot 7$ & 22.8 & 23.8 & 24.8 & 26.0 & $27 \cdot 2$ & \\
\hline & 18.6 & 5 & 2 & $\begin{array}{l}41 \cdot 4 \\
\end{array}$ & $22 \cdot 4$ & 23.5 & $24 \cdot 6$ & 7 & $26 \cdot 9$ & 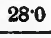 & \multirow{2}{*}{24} \\
\hline \multirow{2}{*}{$93-$} & $19 \cdot 2$ & 20.1 & $21 \cdot 1$ & $22 \cdot 1$ & $23 \cdot 2$ & $24 \cdot 3$ & 25.4 & $26 \cdot 5$ & 27.8 & 29.0 & \\
\hline & $19 \cdot 8$ & 20.8 & 2 & 322.8 & 23.9 & $25 \cdot 0$ & 26.2 & $27 \cdot 4$ & 28.6 & 200 & \multirow[t]{2}{*}{ so } \\
\hline \multirow[t]{2}{*}{97} & 20.4 & 21.4 & $22 \cdot 5$ & $523 \cdot 6$ & $24 \cdot 7$ & 25.8 & 27.0 & 28.3 & 29.5 & $\mathbf{3 0} 8$ & \\
\hline & 211 & $22 \cdot 1$ & $23 \cdot 2$ & $24 \cdot 3$ & 25.5 & 26.6 & $27 \cdot 9$ & 292 & 30.5 & $31 \cdot 8$ & \\
\hline \multirow[t]{2}{*}{99} & 21.7 & 228 & 23.9 & $925 \cdot 0$ & 26 & $27 \cdot 5$ & 28.7 & $30 \cdot 1$ & $31 \cdot 4$ & 0 & \multirow{2}{*}{99} \\
\hline & $22 \cdot 4$ & 23.5 & $24 \cdot 6$ & 25.8 & $27 \cdot 1$ & 28.3 & 29.6 & 31.0 & 32.4 & $33 \cdot 8$ & \\
\hline . & $23 \cdot 0$ & 4.2 & 4 & 26.6 & $27 \cdot 9$ & 29.2 & 30.5 & 31.9 & 33.3 & $4 \cdot 8$ & \\
\hline \multirow[b]{2}{*}{ Uz } & 23.7 & $24: 9$ & $26 \cdot 1$ & $27 \cdot 4$ & 28.7 & 30.1 & 31.4 & 32.9 & $34 \cdot 3$ & $35 \cdot 9$ & \\
\hline & 24 & $\begin{array}{l}25.7 \\
\end{array}$ & 9 & 28.2 & 29.6 & 31.0 & $32 \cdot 4$ & 39.9 & 35.4 & 000 & \multirow{2}{*}{$\begin{array}{r}102 \\
-103\end{array}$} \\
\hline & $25 \cdot 2$ & 26.4 & $27 \cdot 7$ & $29 \cdot 1$ & ${ }^{\prime} 30.5$ & 81.9 & 33.4 & 34.9 & 36.4 & 0 & \\
\hline & 25.9 & $27 \cdot 2$ & 28.5 & $529 \cdot 9$ & $31 \cdot 3$ & 32.8 & $34: 3$ & $85 \cdot 9$ & $37 \cdot 5$ & $39 \cdot 1$ & \\
\hline & $26 \cdot 7$ & 28.0 & $29 \cdot 4$ & 1 $30.8^{\prime}$ & $32 \cdot 2$ & 33.8 & $35 \cdot 3$ & 86.9 & 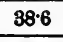 & 0.3 & \\
\hline & 27 & 28.8 & $30 \cdot 2$ & 31.7 & $33 \cdot 2$ & 34.7 & 36.3 & 38.0 & 39.7 & 41.4 & \\
\hline & & $29 \cdot 6$ & $81 \cdot 1$ & $32 \cdot 6$ & $34: 2$ & 35.7 & $37 \cdot 4$ & 001 & 200 & $42 \cdot 6$ & \\
\hline & 29.0 & 30.4 & $81 \cdot 9$ & 33.5 & 35.1 & 36.7 & 38.4 & 40.2 & 42.0 & 13.8 & \\
\hline & $29 \cdot 8$ & $81 \cdot 8$ & 328 & $34 \cdot 4$ & 36.1 & 37:7 & 39.5 & 8 & $43 \cdot 1$ & 45.0 & \\
\hline
\end{tabular}




\begin{tabular}{|c|c|c|c|c|c|c|c|c|c|}
\hline \multirow{4}{*}{$\begin{array}{l}\frac{\bar{n}}{0} \\
\bar{\Sigma} \\
\text { so }\end{array}$} & & \multicolumn{3}{|c|}{ Si (Sitting height) } & \multirow{2}{*}{$-\frac{\overline{0}}{\overline{0}}$} \\
\hline & $i$ & & & 4 & & 6 & 78 & so & \\
\hline & & & & & & \multicolumn{3}{|c|}{ Weight in Kilograms } & \\
\hline & 18.7 & $19 \cdot 5$ & $0 \cdot 3$ & $21 \cdot 1$ & $2 \cdot 0$ & 22.923 .8 & $24.8 \quad 257$ & 26.7 & \\
\hline $\begin{array}{l}\text { S1 } \\
\text { S2 }\end{array}$ & 4 & $\cdot 2$ & $21 \cdot 1$ & $21 \cdot 9$ & $2 \cdot 8$ & $23.7 \quad 24.7$ & $25.7 \quad 26.7$ & $27 \cdot 7$ & \\
\hline \multirow{3}{*}{$\begin{array}{l}\text { S3 } \\
\text { s4 }\end{array}$} & $20 \cdot 1$ & $21 \cdot 0$ & $21 \cdot 8$ & $22 \cdot 7$ & 23.7 & $24 \cdot 625 \cdot 6$ & $26 \cdot 7 \quad 27 \cdot 7$ & $28 \cdot 7$ & \\
\hline & 20.8 & $21 \cdot 7$ & $22 \cdot 6$ & $23 \cdot 6$ & $24 \cdot 6$ & $25.5 \quad 26.6$ & $27 \cdot 6 \quad 28 \cdot 7$ & $29 \cdot 8$ & \\
\hline & $21 \cdot 6$ & $22 \cdot 5$ & 28.5 & $24 \cdot 4$ & $25 \cdot 4$ & $26.5 \quad 27.5$ & $28.629 \cdot 8$ & $30 \cdot 9$ & \\
\hline \multirow{2}{*}{$\begin{array}{l}\text { Si) } \\
\text { S6 }\end{array}$} & $22 \cdot 4$ & $23 \cdot 3$ & $24 \cdot 3$ & $25 \cdot 3$ & $26 \cdot 4$ & $27.4 \quad 28.5$ & $29.7 \quad 30.8$ & $32 \cdot 0$ & \\
\hline & $23 \cdot 2$ & $24 \cdot 1$ & $25 \cdot 2$ & $26 \cdot 2$ & $27 \cdot 3$ & $28.4 \quad 29.5$ & $30 \cdot 7 \quad 31 \cdot 9$ & $33 \cdot 1$ & \\
\hline \multirow{2}{*}{ s7 } & $24: 0$ & $25 \cdot 0$ & $26 \cdot 1$ & $27 \cdot 1$ & $28 \cdot 3$ & $29.4 \quad 30.6$ & $31.8 \quad 33.1$ & $34 \cdot 3$ & \\
\hline & $24 \cdot 8$ & $25 \cdot 9$ & $27 \cdot 0$ & $28 \cdot 0$ & $29 \cdot 2$ & $30 \cdot 4 \quad 31 \cdot 6$ & $32 \cdot 9 \quad 34 \cdot 2$ & $35 \cdot 5$ & \\
\hline s: & $25 \cdot 7$ & $26 \cdot 8$ & $27 \cdot 9$ & $29 \cdot 0$ & $30 \cdot 2$ & $31.5 \quad 32.7$ & $34: 0 \quad 35 \cdot 4$ & $36 \cdot 7$ & \\
\hline \multirow{2}{*}{91} & 26.5 & $27 \cdot 7$ & $28 \cdot 8$ & $30 \cdot 0$ & $31 \cdot 3$ & $32.5 \quad 33.8$ & $35.2 \quad 36.6$ & $38 \cdot 0$ & \\
\hline & $27 \cdot 4$ & $28 \cdot 6$ & 29.8 & $31 \cdot 0$ & $32 \cdot 3$ & $33.6 \quad 35.0$ & $36.4 \quad 37.8$ & 39 & \\
\hline \multirow{2}{*}{93} & $28 \cdot 3$ & 29.5 & $30 \cdot 8$ & $32 \cdot 1$ & $33 \cdot 4$ & $34.7 \quad 36.1$ & $37.6 \quad 39.0$ & 40.5 & \\
\hline & $29 \cdot 3$ & $30 \cdot 5$ & 8 & $33 \cdot 1$ & $34 \cdot 5$ & $35.9 \quad 37 \cdot 3$ & $\begin{array}{|ll|}38.8 & 40.3 \\
\end{array}$ & 41 & \\
\hline 94 & $30 * 2$ & $31 \cdot 5$ & $32 \cdot 8$ & $34 \cdot 2$ & $35 \cdot 6$ & $37 \cdot 0 \quad 38 \cdot 5$ & $40.1 \quad 41 \cdot 6$ & $43 \cdot 2$ & \\
\hline \multirow{2}{*}{$\begin{array}{l}9 i) \\
96\end{array}$} & $31 \cdot 2$ & 32.5 & $33 \cdot 9$ & $35 \cdot 3$ & 36.7 & $38 \cdot 2 \quad 39 \cdot 8$ & $41 \cdot 3 \quad 42 \cdot 9$ & $44 \cdot 6$ & \\
\hline & $32 \cdot 2$ & $33 \cdot 5$ & $35 \cdot 0$ & $36 \cdot 4$ & $37 \cdot 9$ & $39.4 \quad 41.0$ & $42 \cdot 6 \quad 44: 3$ & 46.0 & \\
\hline 17 & $33 \cdot 2$ & 34.6 & $36 \cdot 1$ & $37 \cdot 6$ & $39 \cdot 1$ & $40.7 \quad 42 \cdot 3$ & $44 \cdot 0 \quad 45 \cdot 7$ & $47 \cdot 5$ & \\
\hline \multirow{2}{*}{99} & $34 \cdot 2$ & $35 \cdot 7$ & $37 \cdot 2$ & $38 \cdot 7$ & 40.3 & $42 \cdot 0 \quad 43.6$ & $45 \cdot 4 \quad 47 \cdot 1$ & $48 \cdot 9$ & \\
\hline & $35 \cdot 3$ & $36 \cdot 8$ & $38 \cdot 3$ & $89 \cdot 9$ & $41 \cdot 5$ & $43 \cdot 2 \quad 45 \cdot 0$ & $46 \cdot 8 \quad 48 \cdot 6$ & 50.4 & \\
\hline \multirow{2}{*}{$\begin{array}{l}1010 \\
101\end{array}$} & $36: 3$ & $37 \cdot 9$ & 39.5 & $4 ! \cdot 1$ & $42 \cdot 8$ & $44 \cdot 6 \quad 46 \cdot 3$ & $48 \cdot 2 \quad 50 \cdot 1$ & 52 & \\
\hline & 374 & 39.0 & 40.7 & $42 \cdot 4$ & $44 \cdot 1$ & $45.9 \quad 47.7$ & $49.651 \cdot 6$ & 53.5 & \\
\hline \multirow{3}{*}{$\begin{array}{l}102 \\
103 \\
104\end{array}$} & $38 \cdot 6$ & 40.2 & $41 \cdot 9$ & 43.6 & $45 \cdot 4$ & $47 \cdot 3 \quad 49 \cdot 2$ & $51 \cdot 1 \quad 53 \cdot 1$ & $55 \cdot 1$ & \\
\hline & 39.7 & 41.4 & 43.1 & 44.9 & $46 \cdot 8$ & $48.7 \quad 50.6$ & $\begin{array}{ll}526 & 54 \cdot 7 \\
\end{array}$ & 56.8 & \\
\hline & $40 \cdot 9$ & $42 \cdot 6$ & $44 \cdot 4$ & $46 \cdot 2$ & $48 \cdot 1$ & $50-1 \quad 52 \cdot 1$ & $54 \cdot 2 \quad 56 \cdot 3$ & 58.7 & \\
\hline \multirow{2}{*}{$\begin{array}{l}105 \\
106\end{array}$} & $42^{\circ} 0$ & 48.8 & $45 \cdot 7$ & $\$ 7.6$ & $49 \cdot 5$ & $51.5 \quad 53.6$ & $55.8 \quad 57 \cdot 9$ & 60.1 & \\
\hline & $48 \cdot 2$ & $45 \cdot 1$ & $47 \cdot 0$ & 49.0 & 51.0 & $53.0 \quad 65: 1$ & $57 \cdot 4 \quad 59 \cdot 6$ & $61 \cdot 8$ & \\
\hline \multirow{3}{*}{$\begin{array}{l}107 \\
108 \\
108\end{array}$} & 44:5 & 46.4 & $48 \cdot 3$ & 50.3 & $52 \cdot 4$ & $54.5 \quad 56.7$ & $59.0 \quad 61.3$ & 33.6 & \\
\hline & 45.7 & $47 \cdot 7$ & $49 \cdot 7$ & $51 \cdot 8$ & $53 \cdot 9$ & $56.1 \quad 58.3$ & 60.6680 & 65.4 & \\
\hline & 47.0 & $49 . \hat{0}$ & $51 \cdot 1$ & $63 \cdot 2$ & $55 \cdot 4$ & $57.7 \quad 60.0$ & $62 \cdot 3 \quad 64 \cdot 7$ & 67 & \\
\hline
\end{tabular}




\begin{tabular}{|c|c|c|c|c|c|c|c|c|c|}
\hline \multirow{2}{*}{$\frac{\bar{n}}{\frac{0}{0}}$} & \multicolumn{8}{|c|}{ Si (Sitting height) } & \multirow{2}{*}{ - } \\
\hline & 81 & 9 & 83 & & 85 & 86 & 88 & 0 & \\
\hline \multirow{2}{*}{80} & & & & & & & & & \\
\hline & $27 \cdot 7$ & $28 \cdot 8$ & 29.8 & $30 \cdot 9$ & $32 \cdot 0$ & 83.234 .4 & $35 \cdot 636 \cdot 8$ & 38.0 & \\
\hline \multirow[t]{2}{*}{01} & $28 \cdot 8$ & $29 \cdot 9$ & $31 \cdot 0$ & $32 \cdot 1$ & $33 \cdot 2$ & 3 & $36 \cdot 938 \cdot 2$ & $39 \cdot 5$ & \\
\hline & $29 \cdot 8$ & $31 \cdot 0$ & $32 \cdot 1$ & $33 \cdot 3$ & $34 \cdot 5$ & $35 \cdot 737 \cdot 0$ & $38 \cdot 339 \cdot 6$ & 40 & \\
\hline 0 & $30 \cdot 9$ & $32 \cdot 1$ & 33.3 & $34 \cdot 5$ & $35 \cdot 8$ & $37 \cdot 0$ & $39 \cdot 741 \cdot 0$ & $42 \cdot 4$ & \\
\hline S & $32 \cdot 1$ & $33 \cdot 3$ & $34 \cdot 5$ & $35 \cdot 8$ & $37 \cdot 1$ & 38.439 .7 & $41 \cdot 142.5$ & $44 \cdot 0$ & \\
\hline 85 & $33 \cdot 2$ & $34 \cdot 5$ & 35.7 & $37 \cdot 1$ & $38 \cdot 4$ & 39.841 .2 & $42 \cdot 644 \cdot 1$ & $45 \cdot 6$ & \\
\hline \multirow{2}{*}{ \$7 } & 34.4 & 35.7 & $37 \cdot 0$ & $38 \cdot 4$ & $39 \cdot 7$ & 41.242 .6 & $44 \cdot 145 \cdot 6$ & $47 \cdot 2$ & \\
\hline & 35.6 & $36 \cdot 9$ & $38 \cdot 3$ & $39 \cdot 7$ & $41 \cdot 1$ & $42 \cdot 644 \cdot 1$ & $45 \cdot 7 \quad 47 \cdot 2$ & $48 \cdot 8$ & \\
\hline \multirow[t]{2}{*}{ is } & 36.8 & $38 \cdot 2$ & $39 \cdot 6$ & $41 \cdot 1$ & $42 \cdot 6$ & $44 \cdot 1 \quad 45 \cdot 6$ & $47 \cdot 2 \quad 48 \cdot 9$ & 50.5 & \multirow{2}{*}{-8} \\
\hline & $38 \cdot 1$ & 39.5 & $41 \cdot 0$ & $42 \cdot 5$ & 44.0 & $45 \cdot 6 \quad 47 \cdot 2$ & $48 \cdot 950.5$ & $52 \cdot 3$ & \\
\hline M & $39 \cdot 4$ & 40.9 & $42 \cdot 4$ & 43.9 & $45 \cdot 5$ & $47 \cdot 1 \quad 48 \cdot 8$ & 50.552 .3 & $54 \cdot 0$ & \\
\hline 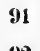 & $40 \% 7$ & $42 \cdot 2$ & 43.8 & 404 & $7 \cdot 0$ & $48 \cdot 7$ & $52 \cdot 254 \cdot 0$ & $55 \cdot 8$ & \\
\hline \multirow[t]{2}{*}{ tz } & $42 \cdot 1$ & $43 \cdot 6$ & $45 \cdot 3$ & $46 \cdot 9$ & $48 \cdot 6$ & $50 \cdot 352 \cdot 1$ & 53.955 .8 & $57 \cdot 7$ & \\
\hline & $43 \cdot 4$ & $45 \cdot 1$ & $46 \cdot 7$ & 48.5 & $50 \cdot 2$ & 8 & 6 & 59 & \\
\hline 94 & 44.8 & 46.8 & $48 \cdot 2$ & $\mathbf{5 0} 0$ & $51 \cdot 8$ & 53.755 .6 & 57.559 .5 & 61. & \\
\hline 93 & $46 \cdot 3$ & $48 \cdot 0$ & 49.9 & 31.6 & 53.4 & 55.4 & 004 & 63 & \\
\hline 96 & $47 \cdot 8$ & 49.5 & $51 \cdot 4$ & $53 \cdot 3$ & $55 \cdot 1$ & $57 \cdot 2 \quad 59 \cdot 2$ & $6 I \cdot 2 \quad 63.4$ & 65 & \\
\hline & $49 \cdot 3$ & $51 \cdot 1$ & $53 \cdot 0$ & 54.9 & $56 \cdot 9$ & 59.061 .0 & 63.265 .3 & $67 \cdot 6$ & \\
\hline & $50^{\circ}$ & 02 & 7 & 56.7 & $8 \cdot 6$ & 60.862 .9 & $65.167 \cdot 4$ & 6 & \\
\hline & $52 \cdot 3$ & $54 \cdot 3$ & $56 \cdot 3$ & 58.4 & 60.5 & 62.764 .9 & $67 \cdot 1 \quad 69 \cdot 4$ & 71.8 & \\
\hline & $54 \cdot 0$ & 56.0 & 58.0 & $60 \cdot 2$ & $62 \cdot 3$ & $66 \cdot 8$ & 1.6 & 740 & \\
\hline & $55 \cdot 6$ & $57 \cdot 7$ & $59 \cdot 8$ & $62 \cdot 0$ & $64 \cdot 2$ & 66.569 .0 & 71.373 .7 & 76.2 & \\
\hline & $57 \cdot 3$ & $59 \cdot 4$ & $61 \cdot 6$ & 63.8 & 66.1 & 9 & 5.9 & 78.5 & \\
\hline & $59 \cdot 0$ & $61 \cdot 1$ & 63.4 & 65.7 & $68 \cdot 1$ & 70.573 .0 & $75 \cdot 678 \cdot 1$ & 80.8 & \\
\hline & 60.7 & $62 \cdot 9$ & $65 \cdot 3$ & $67 \cdot 6$ & 70.1 & $72.6 \quad 75 \cdot 1$ & 80.4 & $83 \cdot 2$ & \\
\hline & 62.4 & $64 \cdot 8$ & $67 \cdot 2$ & $69 \cdot 6$ & $72 \cdot 1$ & $74 \cdot 7 \quad 77 \cdot 3$ & $80.0 \quad 82.7$ & 856 & \\
\hline & $64 \cdot 2$ & 66.6 & $69 \cdot 1$ & 71.6 & $74 \cdot 2$ & 76.879 .5 & $82.385 \cdot 1$ & 88.0 & \\
\hline & $66 \cdot 0$ & 68.5 & $71 \cdot 0$ & $73 \cdot 6$ & $76 \cdot 3$ & 79.081 .8 & $84.787 \cdot 5$ & 90.5 & \\
\hline & 67.9 & 70.4 & 73.0 & $75 \cdot 7$ & $78 \cdot 4$ & $81 \cdot 284 \cdot 1$ & 87.090 .0 & $93 \cdot 1$ & \\
\hline & $69 \cdot 8$ & $72 \cdot 4$ & $75 \cdot 1$ & 77.8 & 80.6 & 83.586 .5 & 89.592 .6 & 957 & \\
\hline
\end{tabular}




\begin{tabular}{|c|c|c|c|c|c|c|c|}
\hline \multirow{3}{*}{$\frac{\overline{0}}{\overline{0}}$} & \multicolumn{6}{|c|}{ Si (Sitting height) } & \multirow[b]{2}{*}{ Е } \\
\hline & 91 & ? & 3 & 95 & . & 100 & \\
\hline & \multicolumn{6}{|c|}{ Weight in Kilograms } & \\
\hline 80 & $\overline{39 \cdot}$ & 40.6 & $42 \cdot 0$ & $43 \cdot 3 \quad 44 \cdot 7$ & $46 \cdot 2 \quad 476$ & $49 \cdot 1 \quad 50 \cdot 6 \quad 52 \cdot 2$ & \\
\hline \multirow[b]{2}{*}{82} & $\overline{40 \cdot 8}$ & $42 \cdot 2$ & $43 \cdot 6$ & $45.0 \quad 46.4$ & $47.9 \quad 49.4$ & $50 \cdot 9 \quad 52 \cdot 5 \quad 54 \cdot 1$ & \\
\hline & $42:$ & 43.7 & $45-2$ & $46.6 \quad 48.1$ & $49 \cdot 7 \quad 51 \cdot 2$ & $52.8 \cdot 54 \cdot 6 \quad 56 \cdot 2$ & \\
\hline \multirow{2}{*}{$\begin{array}{l}83 \\
54\end{array}$} & $43 \cdot 5$ & $45 \cdot 3$ & 46.8 & $48 \cdot 4 \quad 49 \cdot 9$ & $51 \cdot 5 \quad 58 \cdot 1$ & $\begin{array}{lll}54.8 & 56.5 \quad 58.2\end{array}$ & \\
\hline & $45 \cdot$ & $47 \cdot 0$ & $48 \cdot 5$ & $50.1 \quad 51 \cdot 7$ & $58 \cdot 4 \quad 65 \cdot 1$ & $\begin{array}{lll}56.8 & 58.5 & 60.3\end{array}$ & \\
\hline \multirow{2}{*}{$\begin{array}{l}85 \\
56\end{array}$} & $\overline{47 \cdot 1}$ & $48 \cdot 7$ & $50 \cdot 3$ & $51.9 \quad 53.6$ & \begin{tabular}{|ll}
$55 \cdot 3$ & $57 \cdot 1$
\end{tabular} & $\begin{array}{lll}58.8 & 60.6 & 62.5\end{array}$ & \\
\hline & $\overline{48 \cdot 8}$ & $50 \cdot 4$ & $52 \cdot 1$ & $53.8 \quad 55.5$ & \begin{tabular}{|ll}
$57 \cdot 3$ & $59 \cdot 1$
\end{tabular} & $60 \cdot 9^{-} \quad 62 \cdot 8.64 \cdot 7$ & \\
\hline s7 & $\overline{50 \cdot 5}$ & $52 \cdot 2$ & $53 \cdot 9$ & $55 \cdot 7 \quad 57 \cdot 4$ & $59 \cdot 3 \quad 61 \cdot 2$ & $63.065 \cdot 0.67 \cdot 0$ & \\
\hline \multirow{2}{*}{$\begin{array}{l}\text { S5 } \\
\text { 89) }\end{array}$} & $\overline{52 \cdot 2}$ & $54 \cdot 0$ & $55 \cdot 8$ & $57 \cdot 6 \quad 59 \cdot 4$ & $61 \cdot 3 \quad 63 \cdot 3$ & $\begin{array}{lll}65 \cdot 2 & 67 \cdot 8 & 69 \cdot 3\end{array}$ & \\
\hline & $\overline{54.0}$ & 65.8 & $57 \cdot 7$ & $59.5 \quad 61.5$ & $63 \cdot 4 \quad 65 \cdot 5$ & $\begin{array}{lll}67.5 & 69.6 & 71 \cdot 7\end{array}$ & \\
\hline 90 & $\overline{55.9}$ & $57 \cdot 7$ & $59 \cdot 6$ & $61 \cdot 6 \quad 63.5$ & $65.6 \quad 67.6$ & $\begin{array}{lll}69.8 & 71.9 & 74 \cdot 1\end{array}$ & \\
\hline \multirow{2}{*}{91} & $57 \cdot 7$ & 59.6 & $61 \cdot 6$ & $\begin{array}{ll}63 \cdot 6 & 65 \cdot 7\end{array}$ & $67.8 \quad 69 \cdot 9$ & $\begin{array}{lll}72 \cdot 1 & 74 \cdot 3 & 76 \cdot 6\end{array}$ & \\
\hline & $59 \cdot 6$ & 61.6 & 63.7 & $65 \cdot 7 \quad 67 \cdot 9$ & $70.0 \quad 722$ & $\begin{array}{lll}74 \cdot 6 & 76 \cdot 8 & 79 \cdot 1\end{array}$ & \\
\hline \multirow{2}{*}{$\begin{array}{l}93 \\
94\end{array}$} & 61 & $63 \cdot 6$ & $65 \cdot 7$ & $67 \cdot 9 \quad 70.1$ & $72 \cdot 3 \quad 74 \cdot 6$ & $\begin{array}{lll}76.9 & 79.8 & 81 \cdot 7\end{array}$ & \\
\hline & $\overline{63 \cdot 6}$ & $65 \cdot 7$ & $67 \cdot 9$ & 70.172 .4 & $74.7 \quad 77 \cdot 0$ & $79.4 \quad 81.9 \quad 84.4$ & \\
\hline \multirow{2}{*}{$\begin{array}{l}95 \\
96\end{array}$} & $\overline{65 \cdot 6}$ & $67 \cdot 8$ & $70 \cdot 1$ & $72 \cdot 3 \quad 74 \cdot 7$ & $77 \cdot 1 \quad 79 \cdot 5$ & $\begin{array}{lll}82.0 & 84 \cdot 6 & 87 \cdot 1 \\
\end{array}$ & \\
\hline & $67 \cdot 7$ & $70-0$ & $72 \cdot 3$ & $74.6 \quad 77 \cdot 0$ & $79.5 \quad 82.0$ & $\begin{array}{lll}84.6 & 87.2 & 89.9 \\
\end{array}$ & \\
\hline 97 & $69 \cdot 8$ & $372 \cdot 2$ & $74 \cdot 5$ & $770 \quad 79.5$ & $82 \cdot 0 \quad 84 \cdot 6$ & $\begin{array}{lll}87.2 & 89.9 & 92.7 \\
\end{array}$ & \\
\hline \multirow{2}{*}{$\begin{array}{l}98 \\
99\end{array}$} & $\pi 2 \cdot \mathrm{C}$ & $74 \cdot 4$ & $76 \cdot 9$ & $79 \cdot 4 \quad 81 \cdot 9$ & $\begin{array}{|ll|}84.6 & 87 \cdot 2 \\
\end{array}$ & $\begin{array}{lll}89.9 & 92.7 & 95.6 \\
\end{array}$ & \\
\hline & $74 \cdot 2$ & 76.7 & $79 \cdot 2$ & $81 \cdot 8 \quad 84 \cdot 5$ & $87 \cdot 2 \quad 89 \cdot 9$ & $\begin{array}{lll}92.7 & 95.6 & 98.5 \\
\end{array}$ & \\
\hline \multirow{2}{*}{$\begin{array}{l}100 \\
101\end{array}$} & $76:$ & $579 \cdot 0$ & 81.6 & $84: 8 \quad 87 \cdot 0$ & $89.8 \quad 92.6$ & $95.5 \quad 98.4 \quad 101.5$ & \\
\hline & $78 \cdot$ & $81 \cdot 4$ & $81 \cdot 1$ & $\begin{array}{ll}86.8 & 89.7 \\
\end{array}$ & $92.5 \quad 95.4$ & 98.41 & \\
\hline \multirow{2}{*}{$\begin{array}{l}102 \\
103\end{array}$} & $81 \cdot$ & 83.9 & 86.6 & 89.4923 & $95.3 \quad 98.3$ & 101.8104 & \\
\hline & 83: & 586.8 & $9 \cdot 2$ & $92 \cdot 1 \quad 95 \cdot 1$ & $98 \cdot 1 \quad 101 \cdot 2$ & $104 \cdot 310$ & \\
\hline 104 & $86^{\circ}$ & 88.9 & $91 \cdot 8$ & $94.8 \quad 98 \cdot 1$ & $101.0104-2$ & $107 \cdot 4110^{-7} 114^{-2}$ & \\
\hline 05 & $88 \cdot$ & $591 \cdot 4$ & $94 \cdot 4$ & $97.5100 \cdot 7$ & $105 \cdot 9 \quad 107 \cdot 2$ & $110-51$ & \\
\hline \multirow{2}{*}{$\begin{array}{l}106 \\
107\end{array}$} & 91. & $094: 0$ & $97 \cdot 2$ & $100 \cdot 8103.6$ & $106.9 \quad 110.9$ & $118.7 \quad 117-2120.8$ & \\
\hline & & $6 \quad 96.7$ & 8 & $103 \cdot 2106 \cdot 5$ & $109.9 \quad 118.4$ & $116 \cdot 9120 \cdot 5124 \cdot 2$ & \\
\hline \multirow{2}{*}{$\begin{array}{l}108 \\
109\end{array}$} & 96 & 2. $99 \cdot 6$ & 1027 & $106 \cdot 1109 \cdot 5$ & $1180 \quad 116 \cdot 6$ & $120.2 \quad 123.9127 \cdot 7$ & \\
\hline & 98 & $9102 \cdot 2$ & $105 \cdot 6$ & 10201126 & 116.2119 .8 & 1236127 & \\
\hline
\end{tabular}


1 


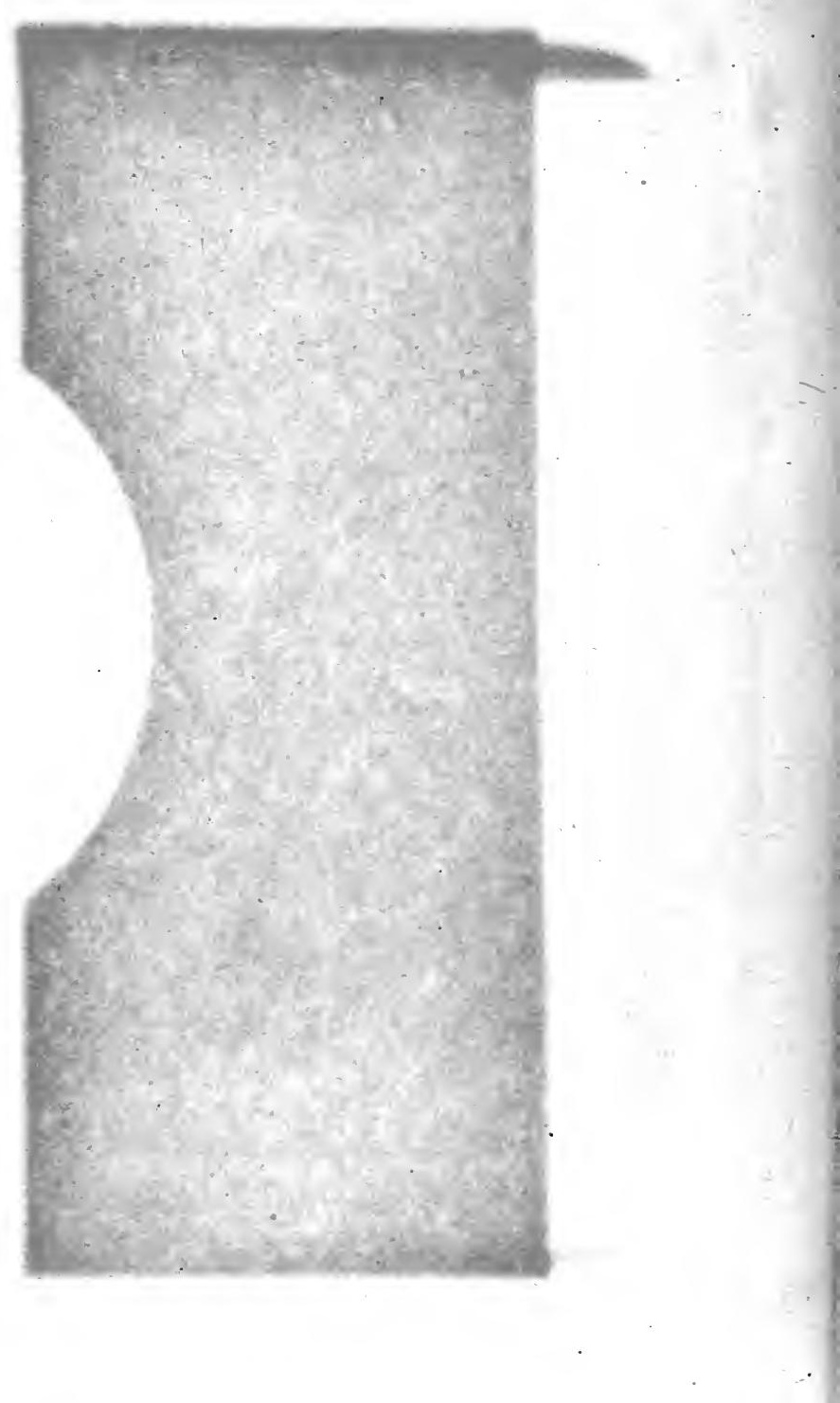




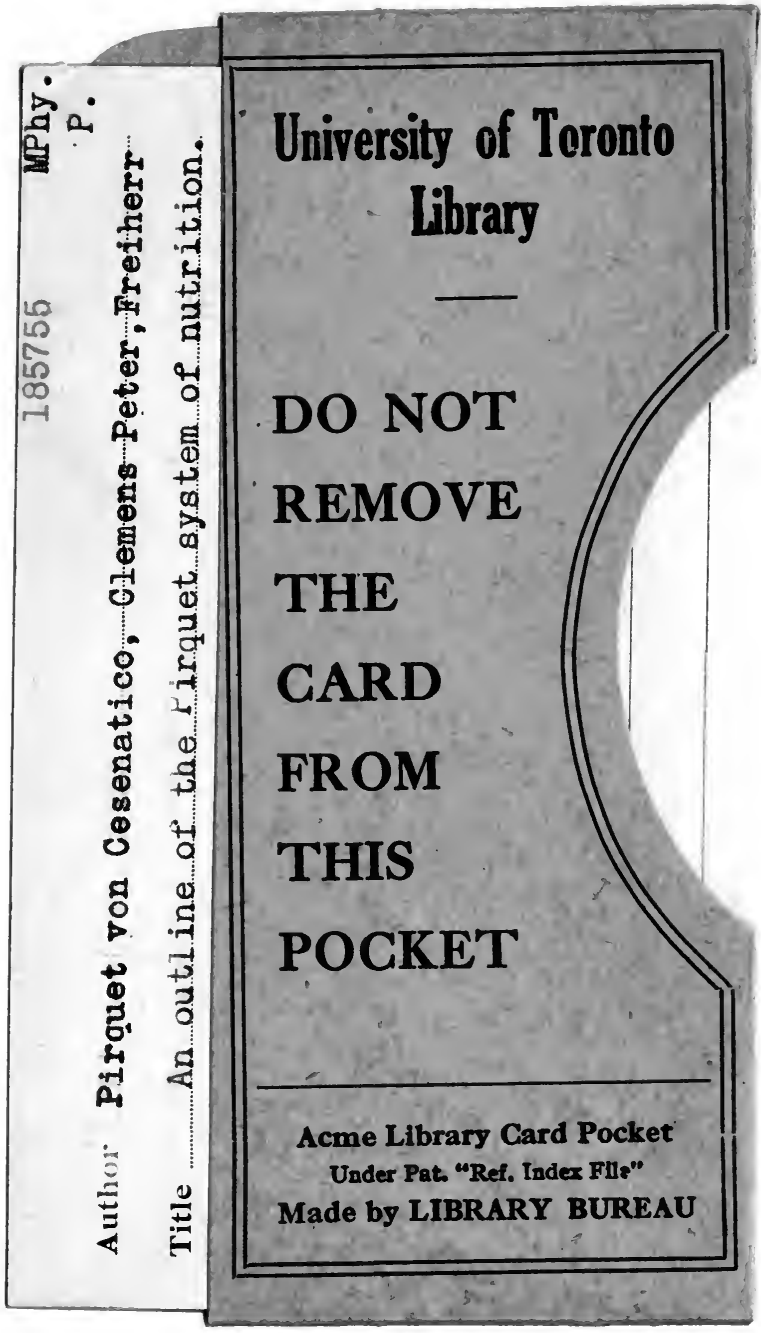


